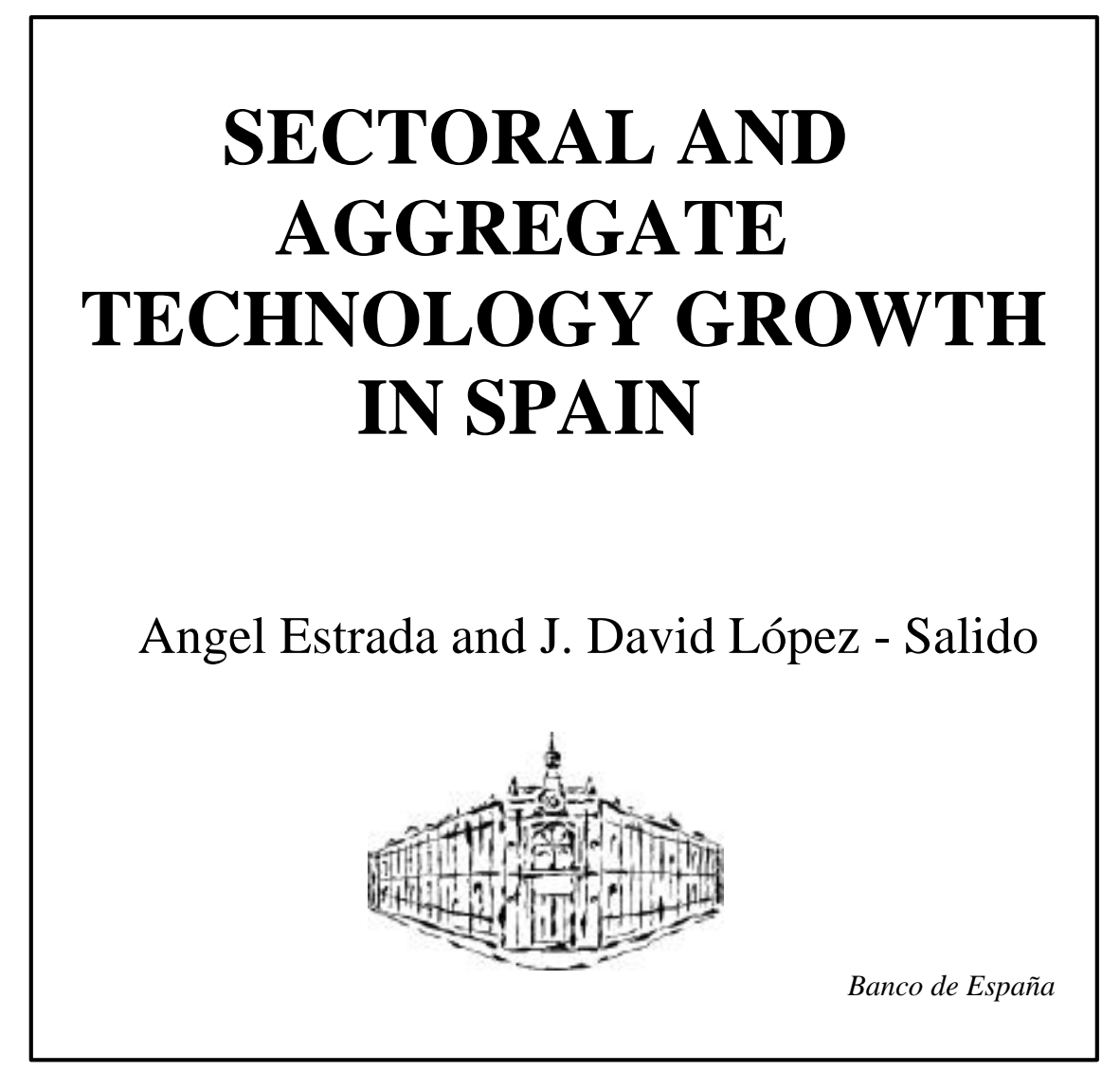

Banco de España - Servicio de Estudios

Documento de Trabajo n. ${ }^{\circ} 0116$ 


\title{
Sectoral and Aggregate Technology Growth in Spain
}

\author{
Angel Estrada $\quad$ J. David López-Salido*
}

October 2001

\begin{abstract}
A bstract
In this paper we analyze technological change in the Spanish economy by constructing adjusted Solow residuals, where the adjustment attempts to correct for the bias associated with the potential presence of imperfect competition, increasing returns, variable input utilization and, especially, sectoral reallocation of inputs across sectors. We refer to this modified Solow residual as a technology index. Sectoral reallocations and variable input utilization are key determinants of the differences between the aggregate Solow residual and the technology index resulting from the aggregation of estimated sectoral technological growth. In particular, we show that technological growth has been in the last two decades more intense than what suggests the standard aggregate Solow residual indices. However, starting in the mid nineties, there has been a deceleration in the aggregate growth rate of technology which is basically due to the behaviour of the manufacturing sectors.
\end{abstract}

\footnotetext{
${ }^{*}$ Correspondence to: Angel Estrada, Banco de España, Research Department, Alcalá 50, 28014 Madrid (Spain). Estrada: estrada@bde.es; López-Salido: davidl@bde.es. We appreciate the comments of participants at the Seminar of the Banco de España and specially those of Soledad Nuñez, Jordi Galí, Fernando Restoy and Javier Vallés. The views expressed here do not necessarily reflect those of the Banco de España. The usual disclaimer applies.
} 


\section{Introduction}

The study of productivity in the Spanish economy has recently been subject to some research, but the papers do not share much in common since it has been analyzed using different sample periods, data sets and methodologies. Notwithstanding, the main conclusions of these studies both in terms of the degree of returns to scale and/or the existence of long-run benefits (i.e. market power) are quite similar, while there are some differences with respect to the presence of external effects and the relevance of unobserved input variation. For instance, Suárez (1992) and Goerlich and Orts (1995) focus on value added data from 1964 to 1989 extracted from the Encuesta Industrial. They found internal decreasing returns to scale for most of the sectors, external effects but without controlling for the potential effects of unobserved input variation. Hernando and Vallés (1994) used firm-level information extracted from the Central de Balances of the Banco de España for the period 1983 to 1989 covering firms in the manufacturing sectors, and they could not reject constant returns to scale and some evidence of external effects. Goerlich and Orts (1997) use gross production and they did not find evidence of external effects nor increasing returns. Recently, Martin and Jaumandreu (1998) and Siotis (2000) have just concentrated on manufacturing firms. Nevertheless, none of these papers have focused on the aggregate implications for technology growth of sectoral reallocations and variable input utilization.

In this paper we proxy technology growth by purguing the Solow residual (i.e. the part of output movements that it is not explained by input's fluctuations) from different sources that do not reflect true technological progress. In particular, we try to account for the presence of increasing returns, the existence of imperfect competition in the good and services markets, the use of intermediate inputs, the importance of variable input utilization, and, more importantly, the reallocation of resources across sectors with different markups.

To that end we use a new data set constructed by compiling National Accounts information and combining it with other sources of information on seventeen sectors, including manufacturing and services sectors, during the period 1980-1999. ${ }^{1}$ To our knowledge there is no other source of microdata that directly aggregates to National Accounts figures. Among other things, this data set makes it possible to compare the relative behavior of productivity growth distinguishing between the sector exposed to external competition and the relatively closed services sector.

\footnotetext{
${ }^{1}$ In a companion paper [Estrada and López-Salido (2001)] we have discussed at length the main characteristics of this data set.
} 
Understanding the differences between these sectors is a relevant research area of the Spanish economy, specially after its incorporation into the euro zone.

Our main results can be described as follows. First, to obtain a disaggregated measure of productivity it is necessary to control for the co-movements between gross production and intermediate inputs in addition to labor and capital. Second, fluctuations in hours, as complementary to employment fluctuations, play an important role to control for unobserved input variation. Third, once we control for those variables we find little evidence of external effects and increasing returns at the sectoral level (i.e., on pure profits). Fourth, although we focus on the estimation of the technology at a sectoral level, we also aim at emphasizing the importance of the reallocation of inputs across sectors in order to understand the trend behavior of the aggregate productivity change. Hence, we show that accounting for reallocation factors across sectors imply important medium term differences in the level of the Solow residuals and the aggregate technology progress arised from individual aggregation. In particular, standard aggregate Solow-residual indices tend to underestimate significantly technological growth in the Spanish economy.

The structure of the paper is as follows. In section 2 we review some new methods for estimating technological progress using output and input variables at a sectoral level. In section 3 we present our main results derived from the estimation of the specification of the production function. Finally, the last section draws some conclusions.

\section{M easuring Technology Growth: Theory}

In this section we describe some methods recently developed for estimating returns to scale and technology growth using output growth regressions, as an alternative to the calculus of the Solow residual (e.g. Estrada and López-Salido (2001) for Spain). We also present how to go from sectoral estimates of technology growth based upon gross production to aggregate technological growth (value added based). Notice that by aggregating from sectoral estimates we control for the bias that arise from using aggregate data instead of sectoral ones. The aggregation among heterogeneous sectors will lead us to clarify the significance of reallocation shifts across sectors. Among these reallocation factors, we pay special attention to changes in the input composition, as well as changes in its degree of utilization, across time and sectors, and the importance of changes in the degree of competition among sectors. 


\subsection{Growth Output R egressions: R eturns to Scale and Imperfect Com- petition}

At the firm level the correct framework to analyze output, and hence productivity, is the production function for gross output as opposed to value added. Without loss of generality we assume that, at time $t$ and for firm $i$, the production function for gross output $\left(Y_{i t}\right)$ takes the following form:

$$
Y_{i t}=F\left(K s_{i t}, L s_{i t}, M_{i t}, A_{i t}\right)
$$

where $K s, L s, M$, and $A$ represent capital services, labor services, intermediate inputs (including energy), and technology (which could include the existence of any sort of possible externality $)^{2}$ respectively. The function $F$ will be assumed to be homogeneous of degree $\gamma_{i}^{F}$ in total inputs. Thus, $\gamma_{i}^{F}=1$ will correspond to constant returns to scale. To measure technology growth, we proceed to take the logarithm of the production function (2.1) and then totally differentiate it to obtain:

$$
\Delta y_{i t}=\frac{F_{K i t} K s_{i t}}{Y_{i t}} \Delta k s_{i t}+\frac{F_{L i t} L s_{i t}}{Y_{i t}} \Delta l s_{i t}+\frac{F_{M i t} M_{i t}}{Y_{i t}} \Delta m_{i t}+\Delta a_{i t}
$$

where $\Delta x_{i t}=\Delta \log X_{i t}$, for $X=Y, K s, L s, M$ and $A$. Expression (2.2) constitutes the basic growth equation of a bulk of papers that followed Solow (1957) and Hall (1988) trying to measure and/or estimate the sources of technological progress.

Thus, one can think of expression (2.2) as a decomposition of the sources of output growth. This is Solow's original idea. To compute $\Delta a_{i t}$ from expression (2.2) we have to derive an expression for the marginal factor productivities, say $F_{J}$ for $J=K s, L s$ and $M$. Hence, we have to incorporate into the analysis the degree of competition in both output and input markets. Under imperfect competition in the goods markets and perfect competition in the factor markets, the firm sets the value of the factor's marginal product equal to a markup over the factor's input prices. Thus, formally:

$$
P_{J_{i t}}=F_{J_{i t}} \frac{P_{i t}}{\mu_{i}}, J=K s, L s, M
$$

where $P_{i t}$ is the output price, $\mu_{i}$ is the markup, and each firm equates the factor prices $\left(P_{J_{i t}}\right)$ to the factor marginal revenue product. Using expression (2.3) it is

\footnotetext{
${ }^{2}$ In Appendix 1 we describe how these effects can be introduced in the analysis.
} 
straightforward to see that the output elasticities can be described as the markup multiplied by the revenue shares of each input in gross output $\left(s_{J}^{F}\right)$ :

$$
\frac{F_{J i t} J_{i t}}{Y_{i t}}=\mu_{i} \frac{P_{J i t} J_{i t}}{P_{i t} Y_{i t}} \equiv \mu_{i} s_{J}^{F}, J=K s, L s, M
$$

Notice that the homogeneity of degree $\gamma_{i}^{F}$ of the production function allows us to write the degree of returns to scale as the sum of the output elasticities with respect to the inputs:

$$
\gamma_{i}^{F}=\frac{F_{K i t} K s_{i t}}{Y_{i t}}+\frac{F_{L i t} L s_{i t}}{Y_{i t}}+\frac{F_{M i t} M_{i t}}{Y_{i t}}
$$

Using expression (2.4) and (2.5) we obtain the following relationship between returns to scale and market power:

$$
\gamma_{i}^{F}=\mu_{i}^{\mu} \frac{\text { totalcost }}{\text { total revenue }}^{\text {ी }}=\mu_{i}\left(1-s_{\pi_{i}}^{F}\right)
$$

where $s_{\pi_{i}}^{F}$ are the pure profits as a percentage over total revenue. Two comments are in order. First, increasing returns will imply that the average cost exceeds marginal cost. ${ }^{3}$ Second, if and only if pure profits are close to zero $\left(s_{\pi_{i}}^{F} \simeq 0\right)$, then the degree of returns to scale is equal to the markup. But, if we observe non-negligible pure profits then, as we will describe below, it is not possible to independently separate or identify returns to scale from markups through the estimation of growth output regressions.

This way, using (2.4) in expression (2.2) it is straightforward to obtain:

$$
\Delta y_{i t}=\mu_{i}\left[s_{K_{i}}^{F} \Delta k s_{i t}+s_{L_{i}}^{F} \Delta l s_{i t}+s_{M_{i}}^{F} \Delta m_{i t}\right]+\Delta a_{i t}
$$

Under constant returns to scale and perfect competition in the product market (i.e. $\gamma_{i}^{F}=\mu_{i}=1$ ), Solow (1957) used the input income shares as observed in the data to weight the input growth. Thus, substituting from the observed output growth the growth rates of the inputs weighted by their respective factor revenue shares, we end up with a calculation of productivity growth, $\Delta a_{i t}$. Under the

\footnotetext{
${ }^{3}$ When the increasing returns are due to fixed cost, then: a) the degree of return to scale is not a parameter but rather a function of the level of output, and b) the existence of increasing returns is compatible with positively sloped marginal cost. In addition, it is still possible that internal increasing returns might result from decreasing marginal cost, but in general there is no necessary relationship between the degree of return to scale and slope of the marginal cost curve.
} 
Solow hypotheses, the residual $\Delta a_{i t}$ in expression (2.7) is uncorrelated with any variable that is uncorrelated with the rate of growth of true productivity. This invariance property of the residual was subject to scrutiny by Hall $(1988,1990)$ who detected that the residual was correlated with exogenous product demand and factor price movements. As increasing returns to scale and imperfect competition will affect movements both in output and inputs, if they are present, they will contaminate the previous measure of productivity growth as truly reflecting technological shocks. In other words, under these new assumptions the output elasticities are not observable from the data. Thus, the strategy changes from the measurement of the residual, $\Delta a_{i t}$, towards the estimation of expression (2.7) as a way of jointly identifying the degree of returns to scale or markups and technology growth.

This expression was advocated by Hall (1988) to (jointly) estimate the markup and technology growth (i.e. the residual, $\Delta a_{i t}$ ), which is now an endogenous variable, by instrumental variables. Notice that the shares are revenue shares, so in the presence of pure profits they add up to less than one. Hall (1990) discusses the possibility of estimating equation (2.7) using cost shares over total costs instead of revenue shares. In such a case, this does not require any assumption on the degree of competition in the goods markets. Under this circumstance, if the so-calculated residual violates the invariance properties, then it is a symptom of increasing returns. To derive this last expression using (2.6) in (2.7) yields:

$$
\Delta y_{i t}=\gamma_{i}^{F}\left[c_{K_{i}}^{F} \Delta k s_{i t}+c_{L_{i}}^{F} \Delta l s_{i t}+c_{M_{i}}^{F} \Delta m_{i t}\right]+\Delta a_{i t}=\gamma_{i}^{F} \Delta x_{i t}^{F}+\Delta a_{i t}
$$

where $c_{K_{i}}^{F} \Delta k s_{i t}+c_{L_{i}}^{F} \Delta l s_{i t}+c_{M_{i}}^{F} \Delta m_{i t}=\Delta x_{i t}^{F}$ is the cost-share weighted average of observed inputs. This expression constitutes the basic equation that we estimate in this paper.

\subsection{Variable Utilization of Capital and Labor}

In this section we explore the implications of allowing for cyclical variations in the utilization of both capital and labor to identify $\gamma_{i}^{F}$ and $\Delta a_{i t}$ in the previous expression (2.8). As noted in the previous section, what matters for production activities are both capital and labor services $(K s, L s)$ as opposed to the stock of those variables. In other words, the production function depends on the quantities of those inputs (hours worked and capital stock) as well as the intensity with which they are used. In general, we can express the capital services as a function of the 
capital stock, $K$, and its degree of utilization, say $U_{K}$. In addition, labor services can be decompose in terms of the number of employees, $N$, the numbers of hours worked, $H$, and the effort of each worker, $E$. Formally, we can write input services as follows: $K s=U_{K} K$, and $L s=N H E=L E$. Allowing for different utilization rates of both capital and labor, leads to a new expression for the output growth regression (2.8):

$$
\Delta y_{i t}=\gamma_{i}^{F}\left[c_{K_{s_{i}}}^{F} \Delta k_{i t}+c_{L_{s_{i}}}^{F} \Delta l_{i t}+c_{M_{i}}^{F} \Delta m_{i t}\right]+\gamma_{i}^{F}\left[c_{K_{s_{i}}}^{F} \Delta u_{c}+c_{L_{s_{i}}}^{F} \Delta e_{i t}\right]+\Delta a_{i t}
$$

where $\Delta l_{i t}=\left(\Delta n_{i t}+\Delta h_{i t}\right)$, and from the definitions of $\Delta x_{i t}^{F}$, the previous expression can be written in the following compact way:

$$
\Delta y_{i t}=\gamma_{i}^{F} \Delta x_{i t}^{F}+\gamma_{i}^{F} \Delta u_{i t}+\Delta a_{i t}
$$

where $\Delta u_{i t}=c_{K_{s_{i}}}^{F} \Delta u_{c}+c_{L_{s_{i}}}^{F} \Delta e_{i t}$, is a weighted average of unobserved variation in capital utilization and effort. Notice that if this effect is present and it is not considered, the estimated technological growth will be contaminated by the cyclical utilization of inputs. Thus, the challenge in estimating expression (2.9) instead of expression (2.8) is to relate the unobservable $\Delta u_{i t}$ to observable variables. In this section we describe the approach followed by Basu and Kimball (1997), although two other alternatives have been suggested in the literature. ${ }^{4}$ Essentially, in order to write unobserved input variation in terms of observable variables, those authors used a cost minimization approach. An usual hypothesis in this formulation is to consider that firms adjust the services of the input by varying utilization, while taking the number of employees and the capital stock as quasi-fixed inputs (so that the firms cannot change their levels at no cost). Under certain assumptions, Basu and Kimball (1997) relate the utilization term in expression (2.9) to three observable variables:

$$
\Delta u_{i t}=a_{i} \Delta h_{i t}+b_{i}\left(\Delta p_{M_{i t}}+\Delta m_{i t}-\Delta p_{I_{i t}}-\Delta k_{i t}\right)+c_{i}\left(\Delta i_{i t}-\Delta k_{i t}\right)
$$

where $\Delta p_{M_{i t}}$ is the growth rate in price of materials, $\Delta p_{I_{i t}}$ is the growth rate in the price of investment goods; and $\left(\Delta i_{i t}-\Delta k_{i t}\right)$ is the rate of growth in investmentcapital ratio. The coefficients $a, b$, and $c$ are combinations of structural parameters. Now, following Basu, Fernald and Kimball (1998) we present the intuition for

\footnotetext{
${ }^{4}$ In Appendix 2 we briefly sumarize these other approaches. In addition we will present how the results are affected by these other alternative identifications (see Appendix 4).
} 
those variables using two polar cases of special interest. These two cases basically depend on the interpretation of hours in expression (2.10).

First, under certain conditions, it is possible to use movements in hours as to proxy unobserved variation in effort and endogenous depreciation rate. The idea is that hours and effort are positively correlated as long as the firm will move both variables following a shock to get the same cost in the margin. Movements in relative input cost shares and investment-capital ratio will capture variable capital utilization. The intuition for the first term is related to the quasi-fixed nature of capital as opposed to the flexible nature of the intermediate inputs. If there is an increase in the utilization of capital, the capital cost will remain the same, but the cost of intermediate inputs will increase due to the increase in the volume used of intermediate inputs. For the second component, the intuition is that an increase in the utilization of capital will mean an increase in the depreciation rate, so more investment is necessary to replace it. A second possibility is to consider that movements in hours capture both labor effort and capital utilization. In this case the parameters $b$ and $c$ in expression (2.10) are zero. As extensively discussed by Basu and Fernald (1997), using conventional data it is not possible to distinguish between labor effort and variable capital utilization. Nevertheless, these authors use a cost-minimization problem for the firm, to show that a reduced-form estimate of the following form: $\Delta u_{i t}=a_{i} \Delta h_{i t}$, is compatible with this joint effect. Under several circumstances this correction for hours will account for capital utilization as well as unobserved labor effort. In addition, these authors provide an structural interpretation to the reduced-form parameter $a_{i}$. They show that the following relation holds:

$$
\Delta u_{i t}=\xi\left[c_{L_{i t}} \Delta h_{i t}\right]
$$

where $\xi=\frac{\bar{H} E^{0}(\bar{H})}{E(\bar{H})}$, is the elasticity of effort with respect to hours, a parameter of crucial importance in calibrating business cycle models (see, for instance, Sbordone (1998)). Thus, the estimated parameter $a$ identifies the elasticity parameter $\xi$.

Finally, one problem of this approach to estimate the degree of returns to scale is that it requires the use of information on the stock of capital at a sectoral level. The construction of this variable is something clearly affected by measurement error problems. Thus, some authors have tried to circumvent this problem by making some parametric assumptions about the functional form of the technology frontier and the degree of capital utilization. In the Appendix 2 we present two 
methods that overcome this problem and we show how it is still possible to identify the course of technological progress. ${ }^{5}$

\subsection{The Bias due to the U se of Value A dded Data}

Often in macroeconomics we refer to value-added data, i.e. to GDP minus indirect taxes and summing up across industries value added has the desirable property of equaling total national expenditure. Thus, regarding the analysis of the degree of returns to scale and markups, Hall $(1988,1990)$ uses value added as a proxy of output (i.e. he uses only information on two inputs, labor and capital), but this approach might have a significant shortcoming in the presence of nonconstant returns to scale and imperfect competition: it can bias the estimation of technological progress. The intuition goes as follows: using National Accounts methodology to calculate value added we are imposing the same constrains as when calculating the Solow Residual. If in this last case the existence of markups or non-constant returns to scale induced a bias in the measure of technological progress due to the departure of input prices from marginal costs, the same will happend with the calculus of value added.

To see this more formally, recall that in the National Accounts methodology, value added is obtained by substracting real material inputs from real gross output (double-deflated value added). Hence, in terms of growth rates the following relation holds: ${ }^{6}$

$$
\Delta v_{i t} \equiv \frac{\Delta y_{i t}-s_{M_{i}}^{F} \Delta m_{i t}}{\left(1-s_{M_{i}}^{F}\right)}=\Delta y_{i t}-{\frac{\mu}{1-s_{M_{i}}^{F}}}^{s_{M_{i}}^{F}} \text { ๆ }\left[\Delta m_{i t}-\Delta y_{i t}\right]
$$

where $\Delta v_{i t}$ represents the rate of growth of value added as opposed to gross production. From that expression it follows that if the ratio of materials to output is constant, then value added grows at the same rate that gross production does. But, in general, this is not the case, hence we can write the value added growth in terms of a cost weighted measure of primary inputs as follows:

$$
\Delta v_{i t}=\rho_{i}\left[\frac{c_{K_{i}}^{F}}{c_{K_{i}}^{F}+c_{L_{i}}^{F}} \quad \Delta k s_{i t}+{\frac{c_{L_{i}}^{F}}{c_{K_{i}}^{F}+c_{L_{i}}^{F}}}^{\text {ๆ }} \Delta l s_{i t}\right]+\Delta \vartheta_{i t}^{*}
$$

\footnotetext{
${ }^{5}$ We also present empirical results based on these alternative approaches as a robustness test for the results presented in the paper (see Appendix 4 for details).

${ }^{6}$ As previously noted, lower case variables denote natural logs of the original variables.
} 
From this expression, two comments are in order. First, it is not clear what the relationship is between the parameter $\rho_{i}$ and the degree of returns to scale $\gamma_{i}^{F}$. Second, the error term $\Delta \vartheta_{i t}^{*}$ only identifies the true technology growth $\left(\Delta a_{i t}\right.$ in expression (2.8)) under certain conditions. To determine these conditions we proceed to find a relationship between expression (2.8) and the previous expression (2.13). Hence, we rearrange expression (2.8) as follows:

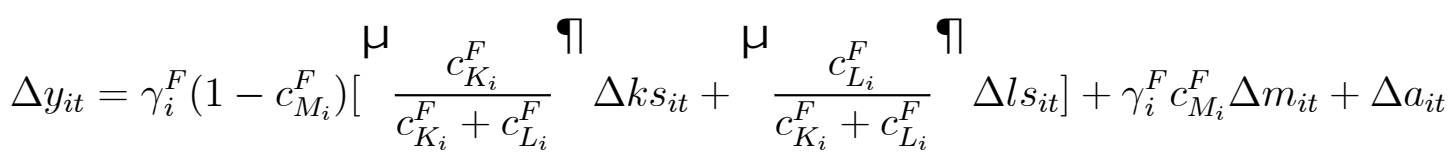

then using (2.12) and cost minimization conditions for intermediate inputs yield:

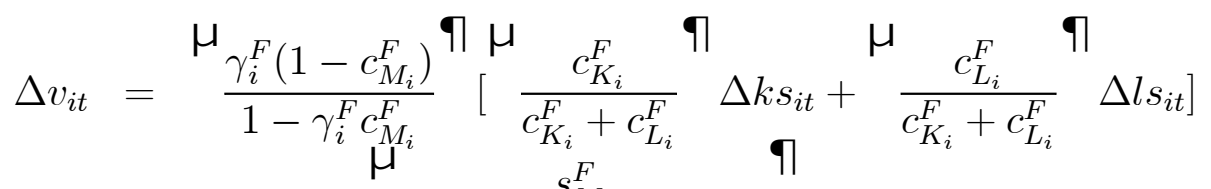

$$
\begin{aligned}
& +\left(\mu_{i}-1\right) \frac{s_{M_{i}}^{F}}{\mu} \frac{\mu}{\left(1-\mu_{i} s_{M_{i}}^{F}\right)\left(1-s_{M_{i}}^{F}\right)}\left[\Delta m_{i t}-\Delta y_{i t}\right]+ \\
& \frac{1}{1-\gamma_{i}^{F} c_{M_{i}}^{F}} \quad \Delta a_{i t}
\end{aligned}
$$

From the comparison of expressions (2.13) and (2.14) we can infer that: first, the coefficient $\rho_{i}=\frac{\gamma_{i}^{F}\left(1-c_{M_{i}}\right)}{1-\gamma_{i}^{F} c_{M_{i}}}$ identifies the degree of returns to scale if and only if there are no materials in the production, something usually far from being the case. The parameter $\rho$ can be interpreted as the degree of returns to scale of a value added function, although under $\rho_{i} \simeq 1$ implies that $\gamma_{i}^{F} \simeq 1$. $^{7}$ Second, the error term in the value-added regression (2.13) takes the form:

$$
\begin{aligned}
\Delta \vartheta_{i t}^{*} & =\left(\mu_{i}-1\right) \frac{s_{M_{i}}^{F}}{\frac{\text { ी }}{\left(1-\mu_{i} s_{M_{i}}^{F}\right)\left(1-s_{M_{i}}^{F}\right)}}\left[\Delta m_{i t}-\Delta y_{i t}\right]+\frac{\mu}{1-\gamma_{i}^{F} c_{M_{i}}^{F}} \Delta a_{i t} \\
\Delta \vartheta_{i t}^{*} & =\Delta \vartheta_{i t}^{M}+\Delta \vartheta_{i t}
\end{aligned}
$$

${ }^{7}$ In particular, as shown by Basu and Fernald (1997), if the production function (2.1) is separable:

$$
Y_{\mathrm{it}}=F\left(V\left(K s_{\mathrm{it}}, L s_{\mathrm{it}}, A_{\mathrm{it}}\right), H\left(M_{\mathrm{it}}\right)\right)
$$

and $F($.$) is homegeneous of degree one in V($.$) and H($.$) , and H($.$) is homogeneous of degree$ one in $M$, then the coefficient $\rho$ can be interpreted as the degree of returns to scale of the value added function $V$, say $\gamma^{\mathrm{V}}$. 
Thus, part of the cyclical movements in the residual of the value added regression do not reflect true technology growth, but rather a hybrid of several variables $\left(\Delta \vartheta_{i t}^{M}\right)$, and the rest is truly technology growth $\left(\Delta \vartheta_{i t}\right)$. The former is a bias that depends on the significance of the degree of imperfect competition and the cyclical behavior of the ratio of materials to output. That term $\left(\Delta \vartheta_{i t}^{M}\right)$ is zero if and only if there is perfect competition (i..e. $\mu_{i}=1$ ) and the elasticity of substitution between intermediate inputs and output is zero and/or the intermediate inputs over total output remains constant over time (i.e. $\Delta m_{i t}=\Delta y_{i t}$ ). The second term, which reflects technology growth, gives a relationship between the production-based technology growth $\left(\Delta a_{i t}\right)$ and the value-added technology growth $\left(\Delta \vartheta_{i t}\right)$. Taking into account the cost share of intermediate inputs, for a reasonable degree of returns to scale in the production funcion, this relationship makes that technology growth in terms of value added will be higher as compared to the production based technology growth. ${ }^{8}$ This will be a key relationship emphasized in this paper. Notice that, both concepts of technology growth are equal if and only if there is no role for intermediate inputs (i.e. $c_{M_{i}}^{F}=0$ ) since in this case value added and gross production are the same.

\subsection{From Sectoral to A ggregate Technology Growth}

So far, we have analyzed the estimation of returns to scale and technology growth in terms of the firm-level production, under several assumptions about technology, market structure, and cyclical factor utilization. Notwithstanding, our focus is on explaining movements in aggregate productivity so we have to aggregate the firms. We devote this section to the issue of aggregation. First, we have to go from gross production to value added, and then we can aggregate over value added. This will made our aggregate technology index comparable with the Solow residual obtained using aggregate data (GDP). Second, we will stress that aggregation across firms can introduce a new source of differences between aggregate productivity growth and the aggregation of sectoral technology indexes: the intersectoral reallocations.

\subsubsection{A ggregate Technology Growth}

First we will derive a relationship between firms' technology growth and aggregate technological growth. As a result, below we will emphasize the importance of

\footnotetext{
${ }^{8}$ Some authors have also emphasized how the presence of external effects can affect this analysis.
} 
reallocation or aggregation effects for understanding the differences between these two variables. In this section we work with the results in terms of an aggregate value-added function that can be constructed from the aggregation of the firmlevel gross-output measures discussed in the previous section. To do that, we proceed to relate the gross-output with value added at the micro level. Hence, the changes in gross output can be described using expression (2.9) which can be reformulated as follows:

$$
\Delta y_{i t}=\gamma_{i}^{F}\left(1-c_{M_{i}}^{F}\right)\left[\Delta x_{i t}^{v}+\Delta u_{i t}\right]+\gamma_{i}^{F} c_{M_{i}}^{F} \Delta m_{i t}+\Delta a_{i t}
$$

where primary input growth $\left(\Delta x_{i t}^{v}\right)$ is defined in terms of the cost shares in value added: $\Delta x_{i t}^{v}=\frac{c_{K_{i}}^{F}}{1-c_{M_{i}}^{F}} \Delta k_{i t}+\frac{c_{L_{i}}^{F}}{1-c_{M_{i}}^{F}} \Delta l_{i t}=c_{K_{i}}^{v} \Delta k_{i t}+c_{L_{i}}^{v} \Delta l_{i t}$. Notice that in the presence of non-constant returns to scale $\left(\gamma_{i}^{F} \neq 1\right)$ or pure profits $\left(c_{M_{i}}^{F} \neq s_{M_{i}}^{F}\right)$, the value added growth obtained as (2.12) does not substract the full productive contribution of materials. In that case there would be an extra term affecting value added growth further than primary input growth. To see this more formally, we can substract both sides of expression $(2.15) \gamma_{i}^{F} c_{M_{i}}^{F} \Delta y_{i t}$ to get:

$$
\Delta y_{i t}=\frac{\gamma_{i}^{F}\left(1-c_{M_{i}}^{F}\right)^{\lrcorner}}{1-\gamma_{i}^{F} c_{M_{i}}^{F}}\left(\Delta x_{i t}^{v}+\Delta u_{i t}\right)+\frac{\gamma_{i}^{F} c_{M_{i}}^{F}}{1-\gamma_{i}^{F} c_{M_{i}}^{F}}\left[\Delta m_{i t}-\Delta y_{i t}\right]+\frac{\Delta a_{i t}}{1-\gamma_{i}^{F} c_{M_{i}}^{F}},
$$

Now, we can define the following variables: $\gamma_{i}^{v} \equiv \frac{\gamma_{i}^{F}\left(1-c_{M_{i}}^{F}\right)}{1-\gamma_{i}^{F} c_{M_{i}}^{F}}$ and $\Delta \vartheta_{i t} \equiv \frac{\Delta a_{i t}}{1-\gamma_{i}^{F} c_{M_{i}}^{F}}$, where the value added returns to scale $\left(\gamma_{i}^{v}\right)$ will be different from gross output returns to scale, and value added technological growth $\left(\Delta \vartheta_{i t}\right)$ will, in general, exceed the gross output technological change. In any case, the implicit value added markup, as shown by Rotemberg and Woodford (1995) and Basu and Fernald (1997), correctly, under some circumstances, captures economy-wide distortions and is plausibly the appropriate concept to calibrate the representative firm in one-sector macroeconomic models. Finally, using the definition of value added (2.12) and substituting from equation (2.16), gives the following expression for the growth of value added:

$$
\Delta v_{i t}=\gamma_{i}^{v}\left(\Delta x_{i t}^{v}+\Delta u_{i t}\right)+\gamma_{i}^{v} \frac{c_{M_{i}}^{F}}{1-c_{M_{i}}^{F}}-\frac{\left(1-s_{\pi_{i}}^{F}\right) c_{M_{i}}^{F}}{1-\left(1-s_{\pi_{i}}^{F}\right) c_{M_{i}}^{F}}{ }^{\lrcorner}\left[\Delta m_{i t}-\Delta y_{i t}\right]+\Delta \vartheta_{i t}
$$


where $s_{\pi_{i}}^{F}$ is the share of pure profits in gross output. From this expression it is clear that only when the ratio of intermediate inputs to gross output remains stable, or when there are no pure profits jointly with constant returns to scale, does forgetting the intermediate inputs to calculate the value added technological change not bias the results. In fact, the value-added productivity residual $\Delta \theta_{i t}=$ $\Delta v_{i t}-\Delta x_{i t}^{v}$, can be written as follows:

$\Delta \theta_{i t}=\left(\gamma_{i}^{v}-1\right) \Delta x_{i t}^{v}+\gamma_{i}^{v} \Delta u_{i t}+\gamma_{i}^{v} \frac{c_{M_{i}}^{F}}{1-c_{M_{i}}^{F}}-\frac{\left(1-s_{\pi_{i}}^{F}\right) c_{M_{i}}^{F}}{1-\left(1-s_{\pi_{i}}^{F}\right) c_{M_{i}}^{F}}\left[\Delta m_{i t}-\Delta y_{i t}\right]+\Delta \vartheta_{i t}$

Aggregating over firms the basic expression for gross output (2.9), in Appendix 3 we show that it corresponds to the following expression for the growth in the aggregate value-added:

$$
\Delta v_{t}=\gamma^{v} \Delta x_{t}^{v}+\Delta u_{t}+R_{t}+\Delta \vartheta_{t}
$$

Thus, $\gamma^{v}$ is the average value added returns to scale index, ${ }^{9} \Delta x_{t}^{v}$ is the weighted (using cost shares) average of the aggregate capital and labor; $\Delta u_{t}$ is the appropriately weighted average of the firm level utilization rates; $R_{t}$ represents various reallocation or aggregation factors, and finally $\Delta \vartheta_{t}$ is an appropriately weighted average of the firm level technology growth. Notice that all of these factors will be constructed starting from the estimation of firm's gross-output regressions like (2.9), so using estimates of $\Delta a_{i t}$. Reallocation shifts make expression (2.19) different to that estimated by Hall (1990) using only aggregate information. That is, the relationship between aggregate technology growth and the aggregation of firm-level technology growth will depend on those reallocation factors. To see this, let us define aggregate productivity growth $\left(\Delta \theta_{t}\right)$ as the difference between the growth rates of aggregate output (value added) and (weighted) aggregate inputs, i.e.: $\Delta v_{t}-\Delta x_{t}^{v}=\Delta \theta_{t}$. Basu and Fernald (1997) call this term a "modified Solow residual". Using this definition in expression (2.19) yields:

$$
\Delta \theta_{t}=\left(\gamma^{v}-1\right) \Delta x_{t}^{v}+\Delta u_{t}+R_{t}+\Delta \vartheta_{t}
$$

This expression offers the basic insight into distinguishing between aggregate productivity growth $\left(\Delta \theta_{t}\right)$ obtained from aggregate information and aggregate

\footnotetext{
${ }^{9}$ See Appendix 3 for a precise description of the parameter identifying the (aggregate) degree of returns to scale, $\gamma^{\mathrm{v}}$.
} 
technology growth $\left(\Delta \vartheta_{t}\right)$ as constructed from individual estimates of expression (2.9). Productivity and technology are equal if and only if all firms are perfectly competitive, pay the same factor prices, do not vary the degree of utilization, there are aggregate constant returns to scale and there are not factor reallocation across sectors. Conceptually, Basu and Fernald (1997) argued that this distributional or reallocative effect may not reflect true technological change, since it can occur with no change in the technology available to the firm. Thus, we should correct the aggregate productivity growth from these factors to get the better approximation to the technical change. These authors show that the measure of aggregate tpchnical change embodied in expression (2.20) takes the following form: $\Delta \vartheta_{t}={ }_{i} \omega_{i} \Delta \vartheta_{i}$; where $\omega_{i}$ is the firm's share of aggregate nominal value added, i.e. $\omega_{i} \equiv \frac{{ }^{i}{ }_{i}^{v} V_{i}}{P^{v} V}$, and $\Delta \vartheta_{i t} \equiv \frac{1}{1-\gamma_{i}^{v} c_{M_{i}}^{v}} \Delta a_{i t}$.

\subsubsection{The R ole of R eallocation Factors}

The reallocation terms reflect the effect on output growth of differences across uses in the values of the marginal product of inputs, i.e. differences in the market power and/or in the factor prices across industries. As shown in Appendix 3, the reallocation term in (2.20) can be decomposed into four major components: $R_{t}=R_{t}^{\mu}+R_{t}^{M}+R_{t}^{K}+R_{t}^{L}$, reflecting shifts of resources among uses with different marginal values. The first two terms reflect the importance of imperfect competition in the product markets. The two other terms are independent of the goods market structure, and reflect sectoral shifts related to idiosyncratic shocks and factor market structures (see Appendix 3 for a formal defition of those terms). $R_{t}^{\mu}$ reflects how the reallocation of resources across firms with different markups will affect the cyclical component of productivity. In other words, this term captures the covariation between inputs's variation and firm market power. The term $R_{t}^{M}$ reflects the extent to which measured real value added depends on the intensity of the materials use and it is affected by the significance of the markups in the firms using materials. The reallocation terms $R_{t}^{K}$ and $R_{t}^{L}$ can be interpreted independently of the existence of imperfect competition. In particular, much of the business cycle literature takes these factors as indicators of sectoral shifts. Thus, shifting capital and labor from sectors where there are high costs to sectors with lower costs will increase aggregate output. Costly factor mobility, adjustment costs or other institutional aspects will generate variability in wages and capital costs across firms, thereby inducing such reallocative terms. 


\section{R esults}

In this section we proceed to estimate equation (2.9) using expressions (2.10) and (2.11) to correct for unobserved variable input utilization. To that end we use a new data set constructed by compiling National Accounts information and combining it with other sources of information on seventeen sectors, including manufacturing and services sectors, during the period 1980-1999. In addition, we analyze how the identification of sectorial and aggregate returns to scale and productivity growth is affected by the use of gross production as opposed to value added data. From an aggregate perspective we then proceed to analyze the implications of our results for the behavior of aggregate technology growth obtained from the aggregation of sectoral estimates as opposed to the constructed Solow residuals using aggregate information. This will allow us to emphasize the importance of the reallocation factors in order to understand the behavior of technology growth in Spain in the last twenty years. Finally, we emphasize that this data set makes it possible to compare the relative behavior of productivity growth distinguishing between the sector exposed to external competition and the relatively closed services sector.

\subsection{Sectoral Estimates of Technology Growth}

In this section we concentrate on discussing the results concerning the estimation of Basu and Kimball especification at the sectoral level. These estimates correspond to the previous expressions (2.9) and (2.10). Since not all the regresors were significant in those expressions, next we will present the estimation, which corresponds to our preferred model, that involves the use of hours as a proxy for the degree of utilization of labor and capital (2.10)..$^{10,11}$

As it has been stressed in the previous sections, there are many circumstances that make the movements in the Solow residual endogenous. Thus, in order to estimate technology growth we require the use of instrumental variable techniques,

\footnotetext{
${ }^{10}$ In Appendix 4 we also present the outcomes of alternative specifications of the production function, to assess the robustness of the exercise.

${ }^{11}$ We tested for the presence of external effects, and we found very little evidence on these. This is due to the fact that our regreessions are based upon the behavior of gross output as opposed to value added. See on this point Burnside (1996). For Spain, this evidence is consistent with the results presented in Goerlich and Orts (1997), and Martín and Jaumandreu (1998). The presence of external effects is usually linked to the use of value added data (see, Suarez (1992), Hernando and Vallés (1994), and Goerlich and Orts (1995)).
} 
due to the a priori correlation between the weighted input growth (and degree of utilization) and technological progress. Adequate instruments would be variables which, on inducing adjustments in the level of production do not change the level of productivity. This suggests the use of demand-side variables. Bearing this in mind we have constructed a fiscal impulse, an indicator of the monetary policy stance, jointly with the growth in world trade. ${ }^{12}$ Finally we also use as an instrument a commodity price, in particular the relative price of energy. These four variables have been included as instruments contemporaneously and lagged one period, and we have extended the set of instruments incorporating the first lag of the variables appearing on the right hand side of each expression. In general, the Sargan tests do not reject the null in all the specifications, so we do not report this test to save space. ${ }^{13}$

The regressions were in each instance performed by GMM and the standard errors are robust to different forms of correlation and heteroskedasticity in the residuals, and to the existence of individual fixed effects. ${ }^{14}$ We present the individual unrestricted estimates of the parameters and, besides, the results imposing that all the parameters are identical across all sectors, and identical for all the manufacturing sectors as opposed to services. Finally, we compare these restricted results with those obtained as the weighted aggregation of the sectoral parameters. $^{15}$

In Table 1 we present the results of the estimation for the general specification of the model (expression (2.9), also allowing for unobserved input variation, i.e. expression (2.10)). As it can be seen, the role of the investment-capital ratio, i.e. the parameter $c$, is null in most of the sectors. It is only significant, and with the right sign (positive) for the sectors Energy (E) and Other Industrial Products (M8). The effect of the ratio of nominal intermediate inputs to capital services, i.e. the coefficient $b$, is estimated with low precision and, in most sectors, where it is significant it has the wrong sign. Notice that, as described in the theoretical part, these two coefficients try to capture the effect of the endogenous depreciation rate as a source of unobserved input variation. Since we are imposing

\footnotetext{
${ }^{12}$ We thank Pablo Hernández de Cos for supplying us with the fiscal impulse. The monetary policy shock was calculated using a SVAR as described by Christiano, Eichenbaum and Evans (1999).

${ }^{13}$ In Appendix 4 we also present estimates using OLS and other two sets of instruments.

${ }^{14}$ The individual effect will capture the average technological growth for each sector over the sample period.

${ }^{15}$ To construct these parameters we use the share of sectoral gross production over total production as a weight.
} 
an exogenous depreciation rate in order to construct our capital series, there are difficulties in capturing such an effect from these estimates. ${ }^{16}$ For that reason, instead of discussing the estimates of the returns to scale and the technological growth implicit in that case, we move to more parsimonious estimates where we only use independent movements in hours to proxy both unobserved labor effort and variable capital utilization as the theory suggests.

In Table 2 we constrain our attention only to the variables that were relevant at standard levels of significance each sector. This is the main reason for having only some sectors with an independent impact of hours so as to capture variable capital utilization and labor effort. The technological growth derived from weighting the sectoral estimates implies that, in terms of gross production, the non-financial market economy has experienced a positively significant growth of the technology evaluated, in annual average terms, at $1 \%$. In addition, the exogenous technological progress, again in terms of gross production, seems to be higher in services $(1.1 \%$, and significant) than in manufacturing $(0.7 \%$, again significant). When we compare these estimates with the restricted ones there seem to be no differences, although we obtain much more imprecise estimates for the aggregate. Furthermore, this lack of precision in the estimates also appears for both the manufacturing and services sectors, where in the latter case there is also a reduction in the point estimates. At a more disaggregated level the sectors that have shown the highest rates of technology growth in terms of gross production are Communications, Agriculture and Chemical products, and the lowest: the Food, Textiles and Other services.

Turning to estimation of the degree of returns to scale, at aggregate level the weighted estimates show that statistically it is not possible to reject the hypothesis of constant returns to scale. Again, there are some differences between manufacturing and services estimates of the returns to scale. We found that the point estimates are higher in the manufacturing sector, but we cannot reject constant returns in both sectors. As previously noted, the restricted estimates do not change these conclusions significantly, although all the estimates are more precisely estimated (see also Burnside (1996)). It is worth mentioning that the point estimates lead to higher returns to scale in services than in manufacturing sector. At a more disaggregated level, the branches presenting constant returns to scale are Minerals, Food, Communications and Other services. In Agriculture, Steel, Transport equipment and Transport services do seem to be some evidence of in-

\footnotetext{
${ }^{16}$ A careful reading of Basu, Fernald and Kimball (1998) leads to similar conclusions for US data.
} 
creasing returns to scale, while we found decreasing returns for Energy, Chemical products, Machinery, Textiles, Other industrial products, Paper, Plastics, Construction and Catering and Trade. Finally, hours play an important independent role in capturing unobserved input variation for the following sectors: Agriculture, Steel, Machinery, Transport equipment, Other industrial products and Transport services and Communications.

As can be seen from Table 2, an interesting result is that the elasticity of effort to hours worked is considerably higher in the manufacturing sector than in the services sector. This will have sizeable effects on the cyclical behavior of total factor productivity in both sectors. Thus, a higher elasticity of effort to hours may account for part of the fluctuations in the Solow residual, so making the true productivity measure less procyclical, specially in the manufacturing setors.

From Appendix 4, it is worth stressing that the results presented in Table 2 are quite robust across the choice of the specification for the production function (i.e. to the use a direct measure of capital to estimate productivity growth). This conclusion is interesting, because one of the criticisms raised to Hall's approach relates to the importance of the existence of measurement error in the calculation of the capital stock regarding the estimation of true technological progress. As long as this variable is only used in the other two alternative production functions to calculate cost shares for the weighted input growth, it seems that the bias potentially induced by the stock of capital it does not seem to be particularly relevant.

As established in the theoretical section, in order to aggregate the sectoral results the first step consists of calculating the implied technology growth and the returns to scale in terms of value added at sectoral level. We do that in order to avoid the double accounting that would appear in the event of directly aggregating gross production results.

We use expressions (2.16) to (2.18) to calculate the technology growth at sectoral level in terms of value added by adjusting for the estimated gross-production returns to scale parameter and the intermediate cost share. In the same vein, the degree of returns to scale in terms of value added is obtained using these two variables. In Table 3 we compare both estimations. As expected, the technology growth in terms of value added is always higher than in terms of gross production (except in the case of Communications). Besides, the correction is more important in the sectors where the returns to scale parameter and the intermediate cost share are bigger. The differences in these two variables in the manufacturing and services sectors explain why technology growth in terms of value added is higher 
in the first case, as opposed to what we obtained using gross production data. The returns to scale parameter in terms of value added also turns out to be different than in terms of gross production. In this case, the adjustment implies an intensification of the degree of returns to scale, and its size depend on the departure from constant returns and the weight of the intermediate inputs. The strong correction induced by the Agriculture and Steel sectors implies that, at the aggregate level, the returns to scale on value added are higher than those estimated using gross production.

In Figure 1 we plot the Solow residual against the estimates of technology growth according to our estimates. In the three cases (total economy, manufacturing and service sectors) there are not very marked differencies in the profiles, but the averages are very different, specially in some sub-periods.

\subsection{A ggregate Implications: The role of Sectorial R eallocation}

The following step consists of analysing of the importance of the reallocation terms linked to the aggregation from sectoral technology growth to the aggregate productivity growth (equation (2.20)). The reallocation terms labeled as markup and intermediate inputs have been calculated using the associated formal definitions (see appendix 3) and the rest are called other reallocation terms (capital and labor reallocation). It should be noticed that the differences between aggregate Solow productivity and the aggregate technology index are not only the reallocation terms, but also the departure from constant returns to scale and the impact of factor utilization. In Table 4 we have derived some descriptive statistics of these time series. The first interesting conclusion to emerge is that the average yearly growth of technology has been higher than productivity, not only for the whole economy, but specially for the manufacturing sector and also for services (see Figures 2 and 3). The most important source of divergence is the departure from constant returns to scale. In general, this term is negative, but the difference between the manufacturing sector and services lies in the combination of increasing returns and an average decrease of the input growth in the former, while the opposite is true for the latter (aggregate economy and services). The variable utilization effect is very small. Overall, the reallocation terms have a negative impact on all the sectors. Nevertheless, this overall negative contribution is the combination of negative markup reallocations (and to a lesser extent intermediate inputs, specially in the manufacturing sector) and positive capital and labor reallocations. The markup component is negative as a result of a general reduction in 
pure profits in the Spanish economy over the sample period (see Figure 2). This reduction was sharper in the manufacturing sector, but it also affects the services sector. Finally, the intermediate reallocation component is quite significant in the manufacturing sector because it uses this input intensively. ${ }^{17}$

Our results imply that aggregate technology growth is less volatile than aggregate productivity as measured by the Solow residual. Nevertheless it is worth noting that these results are affected by the developments in the Steel sector, where the growth rate of the technology has been very high, specially during the first part of the sample. As expected, the reallocation terms present a high volatility. The estimated comovements between technology and output are in line with the evidence obtained using the Solow residual as productivity. At the aggregate level and in the manufacturing sector there is almost no correlation between output and technology, while the sign is positive in the services sectors. The main conclusion reached in the previous section is not affected: adjustments in the inputs used tend to imply a non-positive comovement between technology and output, because short-run reallocation factors are not substantial enough to correct it. The exception is the services sectors.

In Figure 4 we compare the level of the Solow residual with our estimates of technological progress. Thus, notice that changes in the Solow residual may not represent changes in the growth rate of technology, but rather a reallocation of the inputs over time and/or other reallocation terms. Our calculations suggest that there is a sizeable spread, which increases over time between these two measures, and that changes in the input allocation account for the reduction of the Solow residual with respect to our technology index. This highlights the importance of the reallocation terms to capture trend movements in technology progress. This result is of particular importance in the manufacturing sector from the beginning of the sample, and to a lesser extent in the services sector starting in the mid-eighties. Thus, at the aggregate level, the Solow residual was a good proxy of technology growth early in the eighties, and from that period onward it has underestimated true technological growth. Finally, it is worth noting that the technology index varies across these two sectors. Thus, the manufacturing sector has trended significantly upward since the peak of the last recession (i.e. around 1993), while the services sector started to decelerate around the same time. In the latter case, the Solow residual clearly overestimate this slowdown in total factor productivity.

\footnotetext{
${ }^{17}$ When we extend the data to 1999 , the results are essentially the same. This can be seen in Table 5.
} 
Notice that in this figure we extend our previous results on the changes in the level of the technological index for the the sample period 1980-1999. ${ }^{18}$ We compare the Solow residual and the technological index that accounts for the significance of the reallocation terms. Two comments are in order. First, the gap between these two measures is slightly higher using the latest information, and this is true for both sectors (and so for the aggregate). Thus, the Solow residual underestimates the technology progress at the end of the sample with respect to our estimated index. Second, there is substantial divergence in the levels of technology indices across sectors. In particular, in the last four years there is a certain stability both in technological progress and in the Solow residual in the manufacturing sector, while the services sector has seen an increase in the index of technology progress (which is in contrast to the slight slowdown identified by the Solow residual). In terms of the rate of growth, during the last years (95-99), the average annual growth rate of the technology index in the manufacturing sectors was 0.33 percent versus the 0.55 percent of the services sectors.

\section{Conclusions}

Following recent research, we have estimated adjusted Solow residuals at sectoral level -i.e. an index of technology progress-, where the adjustment attempts to correct the bias associated with the potential presence of imperfect competition, increasing returns, the use of intermediate inputs and variable input utilization. We do not find evidence of increasing returns, nor of pure profits among manufacturing and services sectors, but movements in hours help in accounting for variable input utilization (specially in the manufacturing sectors). Once we control for these effects we find no evidence of external effects. After aggregating these results over sectors we show that intersectoral reallocations of inputs have played a key role in explaining the evolution of the Solow residual index in Spain over the last two decades, whose average growth rate has been much lower than the aggregate technology growth. From an aggregate perspective, we show that starting in the mid-nineties, there has been a deceleration in the aggregate growth rate of technology. This is basically due to the behaviour of the manufacturing sectors, since technology growth rate in the services sectors has been slightly higher in that period.

\footnotetext{
${ }^{18}$ See our companion paper, Estrada and López-Salido (2001) for more details on the description of the data for that recent period.
} 


\section{Appendix 1. External Effects}

As noted in the main text the specification for gross output (i.e. (2.8)) can be modified to allow for external effects. In the presence of such an effect an omitted variable problem arises which affects both the estimation of the degree of returns to scale and the properties of the technological progress. We follow Caballero and Lyons (1989) and Burnside (1996) in $\mu^{\mu s i n g}$ an "faggregate ${ }_{3}$ input" as ,an index for external effects. Thus, let us define $\frac{c_{K_{s_{i}}}^{F}}{c_{K_{s_{i}}+c_{L_{s_{i}}}^{F}}} \Delta k s_{i t}+\frac{c_{L_{s_{i}}}}{c_{K_{s_{i}}}+c_{L_{s_{i}}}} \Delta l s_{i t}=$ $\Delta x_{i t}^{v}$ as the cost-share weighted average of observed inputs in the value added exprassion (2.13), then the asgregate input as an externality index is defined as: $\quad{ }_{i} c_{i}^{F} \Delta x_{i t}^{F}=\Delta x_{t}^{F}$, and ${ }_{i} c_{i}^{v} \Delta x_{i t}^{v}=\Delta x_{t}^{v}$, where $c_{i}^{F}$ and $c_{i}^{v}$ represent the cost share of sector $i$ in total costs based on gross production and value added, respectively. In terms of the error term in equations (2.8) and (2.13), would imply that: $\Delta a_{i t}=\eta^{F} \Delta x_{t}^{F}+\Delta a_{i t}^{\prime}$, and $\Delta \vartheta_{i t}=\eta^{v} \Delta x_{t}^{v}+\Delta \vartheta_{i t}^{\prime}$; where the parameters $\eta^{\prime} s$ represent the constant elasticity of the output measure with respect to the externality index. 


\section{Appendix 2. Alternative Ways of Estimating Productivity Growth without using Information on Capital Stock}

A) Complementarity between Electricity Use and Capital Hours (Burnside, Eichenbaum and Rebelo (1997), BER)

Those authors, unlike Basu and Kimball (1997), emphasize that what really matters to measure productivity growth is only to control for (unobserved) variations in capital utilization, disregarding labor effort. In order to identify the circumstances under which the previous statement holds they emphasize that there is a strong complementarity between the electricity or energy use and capital hours in producing capital services. To formalize this idea it has to be assumed that the production function (2.1) is a Leontief function of value-added and materials ${ }^{19}$ :

$$
Y_{i t}=\min \left\{\omega_{v} V\left(K s_{i t}, L s_{i t}, A_{i t}\right), \omega_{M} M_{i t}\right\}
$$

where the parameters $\omega$ are positive constants, the value-added function is assumed to be homogeneous of degree $\gamma^{\Gamma}$ in $K s_{i t}$ and $L s_{i t}$ :

$$
V\left(K s_{i t}, L s_{i t}, A_{i t}\right)=A_{i t} \Gamma\left(K s_{i t}, L s_{i t}\right)
$$

with $L_{i t}=L_{i t}$, and $K s_{i t}=\min \left\{a_{k} K_{i t}, a_{e} E_{i t}\right\}$, i.e. capital services are also a Leontief function of capital hours and energy use. Thus, energy input is a perfect index of capital input. Under these assumptions, in expression (2.9) the following relationship holds ${ }^{20}$ :

$$
\Delta u_{i t}+\Delta k_{i t}=\Delta e_{i t}
$$

Finally, it is still possible to combine the fact that hours can be a proxy for both labor effort and that energy use can also allow independent capital utilization to be identified; i.e. formally, it is still possible to combine expressions (4.1) and (2.10) to allow for cyclical variation in both capital and hours. In particular, if expression (2.10) is satisfied such that $b=c=0$, then we can use expression (4.1) to strip out the capital stock from expression (2.9). So, we end up with the following expression to be estimated in order to measure productivity:

\footnotetext{
${ }^{19}$ They impose that in the technology there are fixed proportions between the observed input and the unobserved inputs. Notice also that in a Leontieff function the degree of substitution among inputs is zero.

${ }^{20}$ Electricity use is a much more natural proxy for the utilization of heavy machinery than for services of structures or computers which are often left on day and night regardless of the use. In addition it is not a good proxy for capital utilization in the Transport Services.
} 


$$
\Delta y_{i t}=\gamma_{i}^{F} \Delta x_{i t}^{F}+\gamma_{i}^{F} a \Delta h_{i t}+\Delta a_{i t}
$$

where now $\Delta x_{i t}^{F}=\left(c_{K_{i}}^{F}+c_{E_{i}}^{F}\right) \Delta e_{i t}+c_{L_{i}}^{F} \Delta l_{i t}+c_{M_{N E_{i}}}^{F} \Delta m n e_{i t}$, with $c_{M_{N E_{i}}}^{F}$ as the non-energy materials cost share and $M_{N E}$ the amount of non-energy intermediate inputs.

B) Variations in Materials Control for both labor effort and capital utilization (Basu (1996))

Unlike the previous analysis, Basu (1996) attempts to control for both labor effort and capital utilization by using alternative assumptions on the production function. He assumes that first the production function (2.1) is separable between value added and materials; second, Hicks' technological progress; and finally, the technology is Leontief in value added and materials. Formally, these assumptions can be written as follows:

$$
Y_{i t}=A_{i t} F\left(V\left(K s_{i t}, L s_{i t}\right), S\left(M_{i t}\right)\right), \text { and } F\left(V_{i t}, S_{i t}\right)=\min \left\{V_{i t}, S_{i t}\right\}
$$

and equation (2.9) takes the following simplest form:

$$
\Delta y_{i t}=\gamma_{i}^{F} \Delta m_{i t}+\Delta a_{i t}
$$

Basu (1996) states that if that assumption does not hold, the estimated value of the returns to scale in these expressions are likely to be biased downward. Thus, a more compelling assumption may be that technology is Leontief in capital services and materials. This would imply that there is a fixed proportion between materials and capital services implying that: $\Delta m_{i t}=\Delta u_{i t}+\Delta k_{i t}$. Again, if we allow for cyclical variation in labor effort, as approximated by expression (2.10) under $b=c=0$, then the growth output regression takes the form:

$$
\Delta y_{i t}=\gamma_{i}^{F} \Delta x_{i t}^{F}+\gamma_{i}^{F} a \Delta h_{i t}+\Delta a_{i t}
$$

where now $\Delta x_{i t}^{F}=\left(c_{K}^{F}+c_{M}^{F}\right) \Delta m_{i t}+c_{L}^{F} \Delta l_{i t}$, which does not depend on the capital stock. ${ }^{21}$

\footnotetext{
${ }^{21}$ This was also suggested by Basu and Kimball (1997), although they do not estimate this expression.
} 


\section{Appendix 3. Aggregation}

We now aggregate the firms to obtain aggregate value-added as a function of aggregate primary inputs, technology and the distribution of inputsp Aggregate input $\$$ are defined as simple sums of firm-level quantities: $K_{t} \equiv{ }_{i} K_{i t}$, and $L_{t} \equiv{ }_{i} L_{i t} .{ }^{22}$ The aggregate price for aggregate inputs is define $\beta$ as the implicit deflator patisfying the following nominal identities: $P_{K_{t}} K_{t} \equiv{ }_{i} P_{K_{i t}} K_{i t}$, and $P_{L_{t}} L_{t} \equiv{ }_{i} P_{L_{i t}} L_{i t}$. Thepvalue added of the economy can be defined, using growth rates, as follows: $\Delta v_{t}={ }_{i} \omega_{i} \Delta v_{i t}, \omega_{i}$ is the firm's share on nominal value added. This way, aggregating firms the expression (2.17) yields:

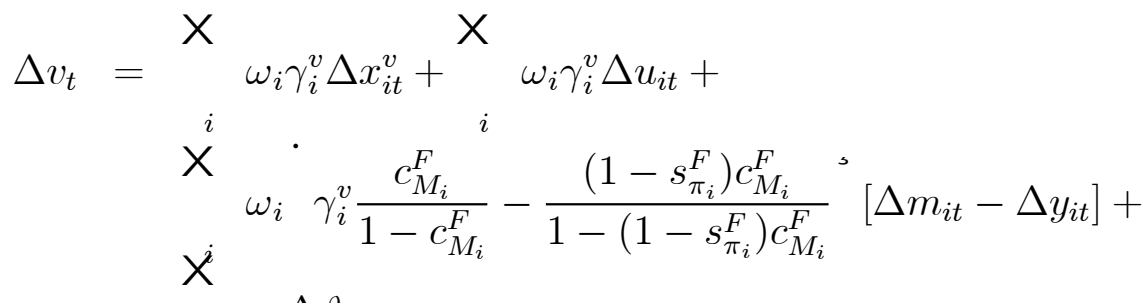

$$
\begin{aligned}
& \omega_{i} \Delta \vartheta_{i t}
\end{aligned}
$$

then we define the following aggregate terms: ${ }^{\mathbf{P}}{ }_{i} \omega_{i} \gamma_{i}^{v} \Delta u_{i t}=\Delta u_{t}$, as the aggregate factor utilization term, ${ }^{\mathrm{P}}{ }_{i} \omega_{i} \gamma_{i}^{v} \frac{c_{M_{i}}^{F}}{1-c_{M_{i}}^{F}}-\frac{\left(1-s_{\pi_{i}}^{F}\right) c_{M_{i}}^{F}}{1-\left(1-s_{\pi_{i}}^{F}\right) c_{M_{i}}^{F}}\left[\Delta m_{i t}-\Delta y_{i t}\right]=R_{t}^{M}$, using the fact that $\frac{s_{\pi_{i}}^{F}}{s_{\pi_{i}}^{v}}=\left(1-s_{M_{i}}^{F}\right)$ and $\gamma_{i}^{v}\left(1-s_{\pi}^{v}\right)=\mu_{i}^{v}$ yields: ${ }_{i} \omega_{i} \frac{s_{M_{i}}^{F}}{1-s_{M_{i}}^{F}}\left[\mu_{i}^{v}-1\right]\left[\Delta m_{i t}-\right.$ $\left.\Delta y_{i t}\right]=R_{t}^{M}$ as the intermediate correction, and ${ }_{i} \omega_{i} \Delta \vartheta_{i t}=\Delta \vartheta_{t}$, as aggregate technology growth.

Since aggregate productivity growth $\left(\Delta p_{t}\right)$ is usually defined as: $\Delta p_{t}=\Delta v_{t}-$ $\Delta x_{t}^{v}$, substituting from (4.5) gives:

$$
\Delta p_{t}={ }_{i}^{\mathrm{X}} \omega_{i} \gamma_{i}^{v} \Delta x_{i t}^{v}-\Delta x_{t}^{v}+\Delta u_{t}+R_{t}^{M}+\Delta \vartheta_{t}
$$

Besides, using definitions and operating we can express $\Delta x_{t}^{v}$ as follows:

$$
\Delta x_{t}^{v}={ }_{i}^{\mathrm{X}} \omega_{i}^{c} \Delta x_{i t}^{v}-{ }_{i}^{\mathrm{X}} \omega_{i}^{c} \frac{c_{K_{i}}^{F}}{1-c_{M_{i}}^{F}} \frac{P_{K_{i t}}-P_{K_{t}}{ }^{\lrcorner}}{P_{K_{i t}}}{ }^{{ }_{i}}{ }_{i} \omega_{i}^{c} \frac{c_{L_{i}}^{F}}{1-c_{M_{i}}^{F}} \frac{P_{L_{i t}}-P_{L_{t}}{ }^{\lrcorner}}{P_{L_{i t}}}
$$

\footnotetext{
${ }^{22}$ We assume there is one type of capital and one type of labor. This can be relaxed without affecting the results (see Basu and Fernald (1997) for details).
} 
where $\omega_{i}^{c}$ is the firm's cost share in gross output costs. Nominating phe second term on the right hand side $R_{t}^{K}$, the third as $R_{t}^{L}$ and defining $\gamma^{v}={ }_{i} \omega_{i} \gamma_{i}^{v}$ we obtain:

$$
\Delta p_{t}=\left(\gamma^{v}-1\right) \Delta x_{t}^{v}+\Delta u_{t}+\gamma^{v} R_{t}^{K}+\gamma^{v} R_{t}^{L}+R_{t}^{M}+R_{t}^{\mu}+\Delta \vartheta_{t}
$$

where:

$$
R_{t}^{\mu}={ }_{i}^{\mathrm{X}} \omega_{i}^{c}\left(\gamma^{v}-\frac{\gamma_{i}^{v}\left(1-s_{\pi}^{v}\right)}{1-s_{\pi}^{v}}\right) \Delta x_{i t}^{v}
$$

using the fact that $\gamma_{i}^{v}\left(1-s_{\pi}^{v}\right)=\mu_{i}^{v}$, the previous expression can be written as follows

$$
R_{\mu_{t}}=\gamma^{v}{ }_{i}^{\mathrm{X}} \omega_{i}^{c}\left(\frac{\mu^{v}-\mu_{i}^{v}}{\mu^{v}}\right) \Delta x_{i t}^{v}
$$




\section{Appendix 4. Data set and Detailed Econometric results: Robust- ness}

Our data set consists on information about 17 productive sectors over the period 1980-1995, on an annual base. These sectors cover the market non-financial side of the Spanish economy. The description of the sectors appears in the next Table A.0. More details can be found in Estrada and López-Salido (2001).

Table A0. Some Definitions

\begin{tabular}{cc}
\hline \hline Sectors Code & Sectors \\
\hline A & Agricultural, Forestry and Fishery \\
E & Fuel and Power Products \\
M1 & Ferron and Non-Ferron Indust. plus Metals ${ }^{23}$ \\
M2 & Non Metallic minerals and Mineral Products \\
M3 & Chemical Products \\
M4 & Ag. and Indust. Machineries ${ }^{24}$ \\
M5 & Transport Equipment \\
M6 & Food, Beverages and Tobacco \\
M7 & Textiles and Clothing, Leather and Footwear \\
M8 & Other Manufacturing Products \\
M9 & Paper and Printing Products \\
M10 & Rubber and Plastic Products \\
C & Building and Constructions \\
S1 & Repair Services, Wholesale and Retail Services ${ }^{25}$ \\
S2 & Inland Transport, Maritime and Air Services \\
S3 & Communication Services \\
S4 & Other Market Services \\
\hline
\end{tabular}

In the main text we have reported the econometric results we obtained when using a specific set of instruments: the relative energy price, world demand, a fiscal and a monetary shock, all of them in $\mathrm{t}$ and $\mathrm{t}-1$ and the right hand side variables lagged one period; besides, the production function considered was a particular one but, as it is shown in Appendix 2, there are other alternatives. In order to assess

\footnotetext{
${ }^{23}$ Metal products except machinery and trompat equipment.

${ }^{24}$ Including Office and Data Processing Machines, Precision and Optical Instruments, and Electric Goods.

${ }^{25}$ Including Accommodation and Catering Services.
} 
the robustness of the results, in this appendix we present different estimations using OLS and other sets of instruments and two other posible specifications of the production function, namely, the BER and Basu approaches. We do not report the Basu and Kimball (BK, henceforth) full specification results because the estimation provided non-significant or incorrectly signed coefficients, and we do not show results with the external effects because they were systematically insignificant. In any case, the full range of results is available upon request.

In Table A.1 we present the same IV estimation than in the main text for the specifications of $B E R$ and Basu. Comparing with $B K$ specification very few differences are detected. The exogenous technological growth estimated is quite similar accross production functions and the ranking of the sectors is not altered (only in the Basu specification Other Services is not one of the sectors showing the poorest performance). The classification of the sectors in terms of the kind of returns to scale they present is also quite robust accross production functions; only in the case of Chemical products every production function gives a different qualification. Finally, the effect of variable factor utilization seems to be independent of the production function considered; only in Machinery and Communications the results are different depending on the production function.

In Table A.2 we present the OLS estimation for the same specifications. Comparing with Table A.1 very few differences are detected (besides, these differences are robust across methodologies): two sectors (Transport Equipment and Transport Services) do not present hours as an additional regressor, and one does (Rubber and Plastic). Moreover, in four sectors the returns to scale parameter is lower (Other Industrial Products, Rubber and Plastic, Communications and Other services).

In Table A.3 we have eliminated the instruments dated contemporaneously. In this case the differences are more substantial. Two sectors (Agriculture and Transport Equipment) do not present an effect of input intensity; in five sectors returns to scale are higher (Agriculture, Energy, Transport Equipment, Textiles and Hotel and Catering) while in the other three they are lower (Steel, Machinery and Communications).

Finally, in Table A.4 we have tried the instrumental set that includes only the exogenous variables dated in $\mathrm{t}$ and $\mathrm{t}-1$. In this case the results are quantitatively and qualitatively similar to the base line instrumental set. Only for Other Industrial products hours are not relevant and only in two sectors (Agriculture and Paper) does the returns to scale parameter seem to be higher. This confirms that exogenous instruments are doing a reasonably good job. 
Table A.1. IV Estimates

Instrumental Variable Estimates (INST-1)

\begin{tabular}{|c|c|c|c|c|c|c|c|c|c|}
\hline & \multicolumn{3}{|c|}{$\overline{c B K}$} & \multicolumn{3}{|c|}{$\overline{B E R}$} & \multicolumn{3}{|c|}{ Basu } \\
\hline & $\begin{array}{l}\text { Fixed } \\
\text { Effect }\end{array}$ & $\gamma^{F}$ & $a$ & $\begin{array}{l}\text { Fixed } \\
\text { Effect }\end{array}$ & $\gamma^{F}$ & $a$ & $\begin{array}{l}\text { Fixed } \\
\text { Effect }\end{array}$ & $\gamma^{F}$ & $a$ \\
\hline \multicolumn{10}{|c|}{ Sectors } \\
\hline A & $\begin{array}{l}3.0 \\
(0.3)\end{array}$ & $\begin{array}{l}1.37 \\
(0.09)\end{array}$ & $\begin{array}{l}1.88 \\
(0.59)\end{array}$ & $\begin{array}{l}2.2 \\
(0.1)\end{array}$ & $\begin{array}{l}1.08 \\
(0.14)\end{array}$ & $\begin{array}{l}1.67 \\
(0.37)\end{array}$ & $\begin{array}{l}2.4 \\
(0.2)\end{array}$ & $\begin{array}{l}1.10 \\
(0.06)\end{array}$ & $\begin{array}{l}1.96 \\
(0.53)\end{array}$ \\
\hline $\mathrm{E}$ & $\begin{array}{l}1.2 \\
(0.7)\end{array}$ & $\begin{array}{l}0.31 \\
(0.03)\end{array}$ & - & $\begin{array}{l}1.4 \\
(0.7)\end{array}$ & $\begin{array}{l}0.25 \\
(0.02)\end{array}$ & - & $\begin{array}{l}1.3 \\
(0.7)\end{array}$ & $\begin{array}{l}0.25 \\
(0.02)\end{array}$ & - \\
\hline M1 & $\begin{array}{l}0.5 \\
(0.1)\end{array}$ & $\begin{array}{l}1.22 \\
(0.01)\end{array}$ & $\begin{array}{l}5.65 \\
(0.30)\end{array}$ & $\begin{array}{l}0.7 \\
(0.1)\end{array}$ & $\begin{array}{l}1.11 \\
(0.01)\end{array}$ & $\begin{array}{l}3.82 \\
(0.67)\end{array}$ & $\begin{array}{l}0.7 \\
(0.1)\end{array}$ & $\begin{array}{l}1.11 \\
(0.01)\end{array}$ & $\begin{array}{l}4.90 \\
(0.54)\end{array}$ \\
\hline M2 & $\begin{array}{c}0.8 \\
(0.3)\end{array}$ & $\begin{array}{l}1.01 \\
(0.03)\end{array}$ & - & $\begin{array}{l}1.0 \\
(0.2)\end{array}$ & $\begin{array}{c}0.99 \\
(0.02)\end{array}$ & - & $\begin{array}{c}0.8 \\
(0.2)\end{array}$ & $\begin{array}{l}0.94 \\
(0.02)\end{array}$ & - \\
\hline M3 & $\begin{array}{l}1.5 \\
(0.1)\end{array}$ & $\begin{array}{l}0.89 \\
(0.03)\end{array}$ & - & $\begin{array}{l}1.4 \\
(0.2)\end{array}$ & $\begin{array}{l}0.83 \\
(0.05)\end{array}$ & - & $\begin{array}{l}1.4 \\
(0.2)\end{array}$ & $\begin{array}{l}0.84 \\
(0.04)\end{array}$ & - \\
\hline M4 & $\begin{array}{l}1.1 \\
(0.1)\end{array}$ & $\begin{array}{l}0.95 \\
(0.01)\end{array}$ & $\begin{array}{l}1.61 \\
(0.23)\end{array}$ & $\begin{array}{l}1.0 \\
(0.1)\end{array}$ & $\begin{array}{l}0.96 \\
(0.02)\end{array}$ & - & $\begin{array}{l}1.2 \\
(0.1)\end{array}$ & $\begin{array}{l}0.91 \\
(0.01)\end{array}$ & $\begin{array}{l}0.75 \\
(0.29)\end{array}$ \\
\hline M5 & $\begin{array}{c}0.9 \\
(0.2)\end{array}$ & $\begin{array}{l}1.07 \\
(0.03)\end{array}$ & $\begin{array}{l}1.50 \\
(0.54)\end{array}$ & $\begin{array}{c}0.6 \\
(0.2)\end{array}$ & $\begin{array}{l}1.00 \\
(0.02)\end{array}$ & $\begin{array}{l}1.45 \\
(0.37)\end{array}$ & $\begin{array}{l}1.3 \\
(0.2)\end{array}$ & $\begin{array}{l}0.97 \\
(0.01)\end{array}$ & $\begin{array}{l}1.53 \\
(0.38)\end{array}$ \\
\hline M6 & $\begin{array}{l}0.1 \\
(0.1)\end{array}$ & $\begin{array}{l}0.98 \\
(0.07)\end{array}$ & - & $\begin{array}{l}0.1 \\
(0.1)\end{array}$ & $\begin{array}{l}1.02 \\
(0.06)\end{array}$ & - & $\begin{array}{l}0.1 \\
(0.1)\end{array}$ & $\begin{array}{l}0.95 \\
(0.06)\end{array}$ & - \\
\hline M7 & $\begin{array}{l}0.4 \\
(0.1)\end{array}$ & $\begin{array}{l}0.84 \\
(0.06)\end{array}$ & - & $\begin{array}{l}0.3 \\
(0.2)\end{array}$ & $\begin{array}{l}0.88 \\
(0.07)\end{array}$ & - & $\begin{array}{l}0.4 \\
(0.1)\end{array}$ & $\begin{array}{l}0.82 \\
(0.05)\end{array}$ & - \\
\hline M8 & $\begin{array}{l}0.8 \\
(0.2)\end{array}$ & $\begin{array}{l}0.87 \\
(0.05)\end{array}$ & $\begin{array}{l}2.72 \\
(0.64)\end{array}$ & $\begin{array}{l}0.6 \\
(0.1)\end{array}$ & $\begin{array}{l}0.83 \\
(0.02)\end{array}$ & $\begin{array}{l}2.77 \\
(0.43)\end{array}$ & $\begin{array}{l}0.8 \\
(0.2)\end{array}$ & $\begin{array}{l}0.85 \\
(0.02)\end{array}$ & $\begin{array}{l}2.69 \\
(0.52)\end{array}$ \\
\hline M9 & $\begin{array}{l}0.7 \\
(0.2)\end{array}$ & $\begin{array}{l}0.71 \\
(0.06)\end{array}$ & - & $\begin{array}{l}0.7 \\
(0.2)\end{array}$ & $\begin{array}{l}0.80 \\
(0.06)\end{array}$ & - & $\begin{array}{l}0.6 \\
(0.2)\end{array}$ & $\begin{array}{l}0.73 \\
(0.06)\end{array}$ & - \\
\hline M10 & $\begin{array}{l}0.9 \\
(0.1)\end{array}$ & $\begin{array}{l}0.92 \\
(0.03)\end{array}$ & - & $\begin{array}{l}0.7 \\
(0.1)\end{array}$ & $\begin{array}{l}0.90 \\
(0.02)\end{array}$ & - & $\begin{array}{l}1.0 \\
(0.1)\end{array}$ & $\begin{array}{l}0.84 \\
(0.01)\end{array}$ & - \\
\hline $\mathrm{C}$ & $\begin{array}{l}1.0 \\
(0.1)\end{array}$ & $\begin{array}{l}0.85 \\
(0.03)\end{array}$ & - & $\begin{array}{l}1.0 \\
(0.1)\end{array}$ & $\begin{array}{l}0.85 \\
(0.03)\end{array}$ & - & $\begin{array}{l}1.0 \\
(0.1)\end{array}$ & $\begin{array}{l}0.84 \\
(0.03)\end{array}$ & - \\
\hline $\mathrm{S} 1$ & $\begin{array}{l}1.2 \\
(0.4)\end{array}$ & $\begin{array}{l}0.69 \\
(0.10)\end{array}$ & - & $\begin{array}{l}1.2 \\
(0.4)\end{array}$ & $\begin{array}{l}0.68 \\
(0.09)\end{array}$ & - & $\begin{array}{l}1.2 \\
(0.4)\end{array}$ & $\begin{array}{l}0.68 \\
(0.09)\end{array}$ & - \\
\hline $\mathrm{S} 2$ & $\begin{array}{l}1.0 \\
(0.3)\end{array}$ & $\begin{array}{l}1.33 \\
(0.12)\end{array}$ & $\begin{array}{l}1.37 \\
(0.78)\end{array}$ & $\begin{array}{l}1.3 \\
(0.3)\end{array}$ & $\begin{array}{l}1.17 \\
(0.03)\end{array}$ & $\begin{array}{l}2.47 \\
(0.43)\end{array}$ & $\begin{array}{l}0.8 \\
(0.2)\end{array}$ & $\begin{array}{l}1.53 \\
(0.08)\end{array}$ & $\begin{array}{l}0.96 \\
(0.21)\end{array}$ \\
\hline $\mathrm{S} 3$ & $\begin{array}{l}3.2 \\
(0.8)\end{array}$ & $\begin{array}{l}1.01 \\
(0.11)\end{array}$ & $\begin{array}{l}4.47 \\
(1.00)\end{array}$ & $\begin{array}{l}2.9 \\
(0.6)\end{array}$ & $\begin{array}{l}0.90 \\
(0.13)\end{array}$ & - & $\begin{array}{l}3.3 \\
(0.7)\end{array}$ & $\begin{array}{c}0.89 \\
(0.10)\end{array}$ & - \\
\hline $\mathrm{S} 4$ & $\begin{array}{l}0.5 \\
(0.4)\end{array}$ & $\begin{array}{l}0.96 \\
(0.11)\end{array}$ & - & $\begin{array}{l}0.4 \\
(0.3)\end{array}$ & $\begin{array}{l}0.96 \\
(0.11)\end{array}$ & - & $\begin{array}{l}1.9 \\
(0.2)\end{array}$ & $\begin{array}{l}0.63 \\
(0.05)\end{array}$ & - \\
\hline
\end{tabular}

Note: INST-1 Instruments include: relative energy prices, world demand, fiscal impulse, and a monetary shock at time $\mathrm{t}$ and $\mathrm{t}-1$; and right hand side variables at t-1. 
Table A 2. OLS Estimates

\begin{tabular}{|c|c|c|c|c|c|c|c|c|c|}
\hline & \multicolumn{3}{|c|}{$\overline{\overline{B B K}}$} & \multicolumn{3}{|c|}{$B E R$} & \multicolumn{3}{|c|}{$\overline{\text { Basu }}$} \\
\hline & $\begin{array}{l}\text { Fixed } \\
\text { Effect }\end{array}$ & $\gamma^{F}$ & $a$ & $\begin{array}{l}\text { Fixed } \\
\text { Effect }\end{array}$ & $\gamma^{F}$ & $a$ & $\begin{array}{l}\text { Fixed } \\
\text { Effect }\end{array}$ & $\gamma^{F}$ & $a$ \\
\hline \multicolumn{10}{|c|}{ Sectors } \\
\hline A & $\begin{array}{l}2.7 \\
(0.8)\end{array}$ & $\begin{array}{l}1.28 \\
(0.28)\end{array}$ & $\begin{array}{l}1.98 \\
(0.87)\end{array}$ & $\begin{array}{l}1.9 \\
(0.7)\end{array}$ & $\begin{array}{l}1.01 \\
(0.23)\end{array}$ & $\begin{array}{l}1.94 \\
(0.89)\end{array}$ & $\begin{array}{l}2.1 \\
(0.7)\end{array}$ & $\begin{array}{l}1.02 \\
(0.23)\end{array}$ & $\begin{array}{l}2.06 \\
(0.89)\end{array}$ \\
\hline $\mathrm{E}$ & $\begin{array}{l}1.3 \\
(0.9)\end{array}$ & $\begin{array}{l}0.46 \\
(0.17)\end{array}$ & - & $\begin{array}{l}1.8 \\
(0.8)\end{array}$ & $\begin{array}{l}0.36 \\
(0.11)\end{array}$ & - & $\begin{array}{c}1.3 \\
(0.8)\end{array}$ & $\begin{array}{l}0.35 \\
(0.12)\end{array}$ & - \\
\hline M1 & $\begin{array}{l}0.6 \\
(0.2)\end{array}$ & $\begin{array}{l}1.22 \\
(0.04)\end{array}$ & $\begin{array}{l}6.11 \\
(1.53)\end{array}$ & $\begin{array}{l}0.7 \\
(0.2)\end{array}$ & $\begin{array}{l}1.13 \\
(0.05)\end{array}$ & $\begin{array}{l}5.08 \\
(1.92)\end{array}$ & $\begin{array}{l}0.7 \\
(0.2)\end{array}$ & $\begin{array}{l}1.12 \\
(0.04)\end{array}$ & $\begin{array}{l}5.06 \\
(1.52)\end{array}$ \\
\hline M2 & $\begin{array}{l}0.7 \\
(0.3)\end{array}$ & $\begin{array}{l}1.03 \\
(0.04)\end{array}$ & - & $\begin{array}{c}0.9 \\
(0.3)\end{array}$ & $\begin{array}{l}0.99 \\
(0.05)\end{array}$ & - & $\begin{array}{l}0.7 \\
(0.3)\end{array}$ & $\begin{array}{l}0.96 \\
(0.04)\end{array}$ & - \\
\hline M3 & $\begin{array}{l}1.5 \\
(0.3)\end{array}$ & $\begin{array}{l}0.91 \\
(0.06)\end{array}$ & - & $\begin{array}{l}1.5 \\
(0.3)\end{array}$ & $\begin{array}{l}0.83 \\
(0.06)\end{array}$ & - & $\begin{array}{l}1.4 \\
(0.3)\end{array}$ & $\begin{array}{l}0.85 \\
(0.06)\end{array}$ & - \\
\hline M4 & $\begin{array}{l}1.4 \\
(0.3)\end{array}$ & $\begin{array}{l}0.91 \\
(0.03)\end{array}$ & $\begin{array}{l}2.72 \\
(1.43)\end{array}$ & $\begin{array}{l}1.3 \\
(0.4)\end{array}$ & $\begin{array}{l}0.92 \\
(0.06)\end{array}$ & - & $\begin{array}{l}1.4 \\
(0.3)\end{array}$ & $\begin{array}{l}0.89 \\
(0.05)\end{array}$ & - \\
\hline M5 & $\begin{array}{l}0.6 \\
(0.4)\end{array}$ & $\begin{array}{l}1.13 \\
(0.03)\end{array}$ & - & $\begin{array}{l}0.4 \\
(0.4)\end{array}$ & $\begin{array}{l}1.07 \\
(0.03)\end{array}$ & - & $\begin{array}{l}0.7 \\
(0.4)\end{array}$ & $\begin{array}{l}1.04 \\
(0.03)\end{array}$ & - \\
\hline M6 & $\begin{array}{l}0.3 \\
(0.3)\end{array}$ & $\begin{array}{l}0.95 \\
(0.10)\end{array}$ & - & $\begin{array}{l}0.3 \\
(0.3)\end{array}$ & $\begin{array}{l}0.91 \\
(0.11)\end{array}$ & - & $\begin{array}{l}0.3 \\
(0.3)\end{array}$ & $\begin{array}{l}0.92 \\
(0.09)\end{array}$ & - \\
\hline M7 & $\begin{array}{c}0.5 \\
(0.2)\end{array}$ & $\begin{array}{l}0.82 \\
(0.07)\end{array}$ & - & $\begin{array}{l}0.5 \\
(0.2)\end{array}$ & $\begin{array}{l}0.81 \\
(0.08)\end{array}$ & - & $\begin{array}{l}0.5 \\
(0.2)\end{array}$ & $\begin{array}{l}0.80 \\
(0.06)\end{array}$ & - \\
\hline M8 & $\begin{array}{l}0.9 \\
(0.3)\end{array}$ & $\begin{array}{l}0.71 \\
(0.07)\end{array}$ & $\begin{array}{l}2.58 \\
(1.03)\end{array}$ & $\begin{array}{l}0.8 \\
(0.4)\end{array}$ & $\begin{array}{l}0.66 \\
(0.07)\end{array}$ & $\begin{array}{l}2.70 \\
(0.99)\end{array}$ & $\begin{array}{l}0.9 \\
(0.4)\end{array}$ & $\begin{array}{l}0.69 \\
(0.07)\end{array}$ & $\begin{array}{l}2.59 \\
(1.04)\end{array}$ \\
\hline M9 & $\begin{array}{l}0.7 \\
(0.5)\end{array}$ & $\begin{array}{l}0.77 \\
(0.08)\end{array}$ & - & $\begin{array}{c}0.8 \\
(0.4)\end{array}$ & $\begin{array}{l}0.82 \\
(0.08)\end{array}$ & - & $\begin{array}{l}0.7 \\
(0.5)\end{array}$ & $\begin{array}{l}0.77 \\
(0.07)\end{array}$ & - \\
\hline M10 & $\begin{array}{l}1.2 \\
(0.2)\end{array}$ & $\begin{array}{l}0.84 \\
(0.04)\end{array}$ & $\begin{array}{l}1.55 \\
(0.49)\end{array}$ & $\begin{array}{l}1.0 \\
(0.2)\end{array}$ & $\begin{array}{l}0.84 \\
(0.03)\end{array}$ & $\begin{array}{l}1.67 \\
(0.44)\end{array}$ & $\begin{array}{l}1.2 \\
(0.2)\end{array}$ & $\begin{array}{l}0.79 \\
(0.03)\end{array}$ & $\begin{array}{l}1.43 \\
(0.45)\end{array}$ \\
\hline $\mathrm{C}$ & $\begin{array}{l}1.0 \\
(0.4)\end{array}$ & $\begin{array}{l}0.87 \\
(0.06)\end{array}$ & - & $\begin{array}{l}1.0 \\
(0.4)\end{array}$ & $\begin{array}{l}0.87 \\
(0.06)\end{array}$ & - & $\begin{array}{l}1.0 \\
(0.4)\end{array}$ & $\begin{array}{l}0.86 \\
(0.06)\end{array}$ & - \\
\hline S1 & $\begin{array}{l}1.5 \\
(0.7)\end{array}$ & $\begin{array}{l}0.60 \\
(0.22)\end{array}$ & - & $\begin{array}{l}1.5 \\
(0.7)\end{array}$ & $\begin{array}{l}0.61 \\
(0.20)\end{array}$ & - & $\begin{array}{l}1.5 \\
(0.7)\end{array}$ & $\begin{array}{l}0.61 \\
(0.21)\end{array}$ & - \\
\hline S2 & $\begin{array}{l}0.4 \\
(0.6)\end{array}$ & $\begin{array}{l}1.32 \\
(0.29)\end{array}$ & - & $\begin{array}{l}0.6 \\
(0.3)\end{array}$ & $\begin{array}{l}1.06 \\
(0.08)\end{array}$ & - & $\begin{array}{l}0.6 \\
(0.5)\end{array}$ & $\begin{array}{l}1.24 \\
(0.21)\end{array}$ & - \\
\hline S3 & $\begin{array}{l}2.6 \\
(1.4)\end{array}$ & $\begin{array}{l}0.90 \\
(0.20)\end{array}$ & - & $\begin{array}{l}2.9 \\
(1.1)\end{array}$ & $\begin{array}{l}0.66 \\
(0.22)\end{array}$ & - & $\begin{array}{l}3.5 \\
(1.2)\end{array}$ & $\begin{array}{l}0.55 \\
(0.19)\end{array}$ & - \\
\hline $\mathrm{S} 4$ & $\begin{array}{l}0.9 \\
(0.9)\end{array}$ & $\begin{array}{l}0.85 \\
(0.20)\end{array}$ & - & $\begin{array}{l}2.1 \\
(0.8)\end{array}$ & $\begin{array}{l}0.51 \\
(0.18)\end{array}$ & - & $\begin{array}{l}2.2 \\
(0.4)\end{array}$ & $\begin{array}{l}0.52 \\
(0.10)\end{array}$ & - \\
\hline
\end{tabular}


Table A 3. IV Estimates

Instrumental Variable Estimates (INST-2)

\begin{tabular}{ccccccccccc}
\hline \hline & & BK & \multicolumn{3}{c}{ BER } & \multicolumn{5}{c}{ Basu } \\
& $\begin{array}{c}\text { Fixed } \\
\text { Effect }\end{array}$ & $\gamma^{F}$ & $a$ & $\begin{array}{c}\text { Fixed } \\
\text { Effect }\end{array}$ & $\gamma^{F}$ & $a$ & Fixed & $\gamma^{F}$ & $a$ \\
\hline Sectors & & & & & & & & & \\
A & 3.5 & 1.76 & - & 2.5 & 1.54 & - & 2.8 & 1.42 & - \\
& $(0.5)$ & $(0.13)$ & & $(0.3)$ & $(0.16)$ & & $(0.4)$ & $(0.13)$ & \\
E & 2.0 & 0.59 & - & 1.8 & 0.39 & - & 1.8 & 0.42 & - \\
& $(0.9)$ & $(0.29)$ & & $(0.6)$ & $(0.16)$ & & $(0.6)$ & $(0.17)$ & \\
M1 & 0.5 & 1.00 & 6.85 & 0.7 & 1.08 & 3.75 & 0.6 & 1.03 & 5.22 \\
& $(0.2)$ & $(0.07)$ & $(2.04)$ & $(0.1)$ & $(0.04)$ & $(1.19)$ & $(0.2)$ & $(0.05)$ & $(1.19)$ \\
M2 & 0.9 & 1.04 & - & 1.1 & 1.02 & - & 0.9 & 0.98 & - \\
& $(0.3)$ & $(0.03)$ & & $(0.3)$ & $(0.03)$ & & $(0.3)$ & $(0.04)$ & \\
M3 & 1.5 & 0.82 & - & 1.6 & 0.73 & - & 1.3 & 0.80 & - \\
& $(0.3)$ & $(0.13)$ & & $(0.3)$ & $(0.10)$ & & $(0.3)$ & $(0.12)$ & \\
M4 & 1.3 & 083 & - & 1.2 & 0.88 & - & 1.3 & 0.83 & - \\
& $(0.3)$ & $(0.05)$ & & $(0.3)$ & $(0.04)$ & & $(0.2)$ & $(0.04)$ & \\
M5 & 0.3 & 1.23 & - & 0.1 & 1.16 & - & 0.5 & 1.12 & - \\
& $(0.5)$ & $(0.07)$ & & $(0.5)$ & $(0.07)$ & & $(0.5)$ & $(0.06)$ & \\
M6 & 0.2 & 1.07 & - & 0.3 & 1.03 & - & 0.3 & 1.01 & - \\
& $(0.3)$ & $(0.05)$ & & $(0.3)$ & $(0.06)$ & & $(0.3)$ & $(0.05)$ & \\
M7 & 0.3 & 1.08 & - & 0.2 & 1.10 & - & 0.2 & 1.05 & - \\
& $(0.2)$ & $(0.13)$ & & $(0.2)$ & $(0.11)$ & & $(0.2)$ & $(0.10)$ & \\
M8 & 1.3 & 0.91 & 6.31 & 1.0 & 0.87 & 6.36 & 1.4 & 0.93 & 6.65 \\
& $(0.4)$ & $(0.15)$ & $(1.50)$ & $(0.5)$ & $(0.14)$ & $(1.49)$ & $(0.4)$ & $(0.17)$ & $(1.62)$ \\
M9 & 0.8 & 0.66 & - & 0.8 & 0.75 & - & 0.8 & 0.68 & - \\
& $(0.3)$ & $(0.05)$ & & $(0.3)$ & $(0.05)$ & & $(0.2)$ & $(0.05)$ & \\
M10 & 1.2 & 0.83 & - & 1.1 & 0.80 & - & 1.0 & 0.82 & - \\
& $(0.4)$ & $(0.09)$ & & $(0.4)$ & $(0.08)$ & & $(0.3)$ & $(0.05)$ & \\
C & 0.6 & 0.91 & - & 0.7 & 0.90 & - & 0.6 & 0.91 & - \\
S1 & $(0.3)$ & $(0.05)$ & & $(0.3)$ & $(0.05)$ & & $(0.3)$ & $(0.04)$ & \\
S2 & 0.7 & 0.90 & - & 0.8 & 0.83 & - & 0.7 & 0.88 & - \\
S3 & $(0.6)$ & $(0.18)$ & & $(0.5)$ & $(0.16)$ & & $(0.6)$ & $(0.17)$ & \\
& 0.6 & 1.23 & - & 1.3 & 1.26 & 2.63 & 0.9 & 1.56 & 1.24 \\
S4 & $(0.5)$ & $(0.26)$ & & $(0.3)$ & $(0.10)$ & $(0.55)$ & $(0.2)$ & $(0.13)$ & $(0.45)$ \\
& 3.4 & 0.76 & - & 3.6 & 0.85 & - & 4.5 & 0.56 & - \\
& $(1.4)$ & $(0.22)$ & & $(1.0)$ & $(0.25)$ & & $(1.1)$ & $(0.22)$ & \\
& -1.5 & 1.50 & - & 0.2 & 1.02 & - & 2.4 & 0.58 & - \\
& $(1.3)$ & $(0.38)$ & & $(1.0)$ & $(0.32)$ & & $(0.5)$ & $(0.09)$ & \\
& & & & & & & & &
\end{tabular}

Note: INST-2 include: Relative energy prices, world demand, fiscal impulse and monetary policy shocks as well as the right hand side variables dated at t- 1 . 
Table A 4. IV Estimates

Instrumental Variable Estimates (INST-3)

\begin{tabular}{ccccccccccc}
\hline \hline & \multicolumn{3}{c}{ BK } & \multicolumn{3}{c}{ BER } & \multicolumn{5}{c}{ Basu } \\
& $\begin{array}{c}\text { Fixed } \\
\text { Effect }\end{array}$ & $\gamma^{F}$ & $a$ & $\begin{array}{c}\text { Fixed } \\
\text { Effect }\end{array}$ & $\gamma^{F}$ & $a$ & Fixed & $\gamma^{F}$ & $a$ \\
\hline Sectors & & & & & & & & & & \\
A & 3.8 & 2.17 & - & 2.3 & 1.53 & - & 2.6 & 1.46 & 1.85 \\
& $(0.3)$ & $(0.32)$ & & $(0.2)$ & $(0.19)$ & & $(0.3)$ & $(0.26)$ & $(0.94)$ \\
E & 0.9 & 0.30 & - & 0.8 & 0.23 & - & 0.8 & 0.22 & - \\
& $(0.7)$ & $(0.05)$ & & $(0.6)$ & $(0.03)$ & & $(0.7)$ & $(0.03)$ & \\
M1 & 0.6 & 1.18 & 5.49 & 0.7 & 1.11 & 3.40 & 0.7 & 1.08 & 4.55 \\
& $(0.1)$ & $(0.04)$ & $(0.82)$ & $(0.1)$ & $(0.03)$ & $(0.71)$ & $(0.1)$ & $(0.02)$ & $(0.68)$ \\
M2 & 0.8 & 1.00 & - & 1.0 & 0.97 & - & 0.8 & 0.93 & - \\
& $(0.3)$ & $(0.01)$ & & $(0.2)$ & $(0.03)$ & & $(0.3)$ & $(0.04)$ & \\
M3 & 1.6 & 0.86 & - & 1.5 & 0.82 & - & 1.4 & 0.82 & - \\
& $(0.2)$ & $(0.05)$ & & $(0.2)$ & $(0.05)$ & & $(0.2)$ & $(0.05)$ & \\
M4 & 1.1 & 0.93 & 1.86 & 1.0 & 0.96 & - & 1.2 & 0.90 & 1.35 \\
& $(0.1)$ & $(0.03)$ & $(0.38)$ & $(0.1)$ & $(0.02)$ & & $(0.2)$ & $(0.02)$ & $(0.73)$ \\
M5 & 1.0 & 1.05 & 1.61 & 0.6 & 1.00 & 1.54 & 1.2 & 0.96 & 1.72 \\
& $(0.2)$ & $(0.03)$ & $(0.62)$ & $(0.3)$ & $(0.04)$ & $(0.80)$ & $(0.2)$ & $(0.02)$ & $(0.59)$ \\
M6 & 0.0 & 0.99 & - & 0.1 & 1.02 & - & 0.1 & 0.95 & - \\
& $(0.1)$ & $(0.07)$ & & $(0.1)$ & $(0.06)$ & & $(0.1)$ & $(0.07)$ & \\
M7 & 0.4 & 0.83 & - & 0.3 & 0.86 & - & 0.4 & 0.81 & - \\
M8 & $(0.1)$ & $(0.05)$ & & $(0.2)$ & $(0.07)$ & & $(0.1)$ & $(0.05)$ & \\
& 0.5 & 0.79 & - & 0.3 & 0.81 & - & 0.5 & 0.77 & - \\
M9 & $(0.4)$ & $(0.10)$ & & $(0.5)$ & $(0.15)$ & & $(0.4)$ & $(0.09)$ & \\
& 0.3 & 0.82 & - & 0.4 & 0.90 & - & 0.2 & 0.87 & - \\
M10 & $(0.2)$ & $(0.08)$ & & $(0.3)$ & $(0.11)$ & & $(0.3)$ & $(0.10)$ & \\
& 0.9 & 0.90 & - & 0.6 & 0.90 & - & 1.0 & 0.84 & - \\
C & $(0.2)$ & $(0.04)$ & & $(0.1)$ & $(0.02)$ & & $(0.1)$ & $(0.01)$ & \\
S1 & 1.0 & 0.84 & - & 1.0 & 0.85 & - & 1.0 & 0.84 & - \\
S2 & $(0.1)$ & $(0.04)$ & & $(0.1)$ & $(0.04)$ & & $(0.1)$ & $(0.04)$ & \\
& 1.1 & 0.72 & - & 1.1 & 0.72 & - & 1.2 & 0.71 & - \\
S3 & $(0.4)$ & $(0.11)$ & & $(0.4)$ & $(0.10)$ & & $(0.4)$ & $(0.11)$ & \\
S4 & 0.5 & 1.46 & - & 1.4 & 1.20 & 3.40 & 0.4 & 1.44 & - \\
& $(0.4)$ & $(0.26)$ & & $(0.2)$ & $(0.05)$ & $(0.90)$ & $(0.2)$ & $(0.09)$ & \\
& 3.5 & 0.83 & 6.33 & 3.1 & 0.81 & - & 3.9 & 0.72 & - \\
& $(1.2)$ & $(0.21)$ & $(2.50)$ & $(0.6)$ & $(0.11)$ & & $(0.8)$ & $(0.12)$ & \\
& 0.0 & 1.09 & - & -0.1 & 1.08 & - & 2.0 & 0.62 & - \\
& $(0.6)$ & $(0.16)$ & & $(0.6)$ & $(0.17)$ & & $(0.2)$ & $(0.05)$ & \\
& & & & & & & & &
\end{tabular}

Note: INST-3 include: Relative energy prices, world demand, fiscal impulse and monetary policy shocks dated at $\mathrm{t}$ and $\mathrm{t}-1$. 


\section{REFERENCES}

Basu, S. (1996): "Cyclical Productivity: Increasing Returns or Cyclical Utilization?", Quarterly Journal of Economics, 111, 719-751.

Basu, S. and J. G. Fernald (1997): "Aggregate Productivity and Aggregate Technology", International Finance Discussion Papers 593, Board of Governors of the Federal Reserve System.

Basu, S. and M. S. Kimball (1997): "Cyclical productivity with Unobserved Input Variation", Working Paper 5915, NBER.

Basu, S., Fernald J. G. and M. S. Kimball (1998): "Are Technology Improvements Contractionary?", International Finance Discussion Papers 625, Board of Governors of the Federal Reserve System.

Burnside, C. (1996): "Production Function Regressions, Returns to Scale and Externalities", Journal of Monetary Economics, 37, 2.

Burnside, C., Eichenbaum, M. S. and S. T. Rebelo (1997): "Capital Utilization and Returns to Scale", NBER Macroeconomics Annual 10, 67-110.

Caballero, R. J. and R. K. Lyons (1989): "The Role of External Economies in US Manufacturing", Working Paper 3033, NBER.

Estrada, A. and J.David López-Salido (2001): "Accounting for Spanish Productivity Growth using Sectoral Data: New Evidence", Banco de España Working Paper 0110.

Fundación BBV (1998): "El Stock de Capital en España y su Distribución territorial", Fundación BBV.

Goerlich, F. J. y V. Orts (1995): "Margen Precio Coste Marginal y Economías de Escala en la Industria Española: 1964-1989”, Documento WP-EC 9501, Instituto Valenciano de Investigaciones Económicas.

Goerlich, F. J. y V. Orts (1996): "Economías de Escala, Externalidades y Atesoramiento del Trabajo en la Industria Española (1964-1989)", Revista de Economía Aplicada, IV, II.

Hall, R. (1988): "The Relation between Price and Marginal Cost in US Industry", Journal of Political Economy 39.

Hall, R. (1990): "Invariance Properties of Solow's Productivity Residual", in Peter Diamond (ed.) Growth, Productivity and Unemployment. Essays to celebrate Robert Solow's Birthday. The MIT press.

Hernando, I. y J. Vallés (1994): "Algunas Diferencias en la Productividad de las Empresas Manufactureras Españolas", Investigaciones Económicas, XVIII, 1.

Instituto Nacional de Estadística (INE): "Contabilidad Nacional de España", Different Issues. 
Martín, A. and J. Jaumandreu (1998): "Entry, Exit and Productivity Growth in Spanish Manufacturing During the Eighties", Documento de Trabajo 9804, Fundación Empresa Pública.

Rotemberg, Julio, and Michael Woodford (1995), "Dynamic General Equilibrium Models with Imperfectly Competitive Product Markets", in Frontiers of Business Cycle Research, Thomas F. Cooley, ed., 243-293, Pinceton University Press, Princeton New Jersey.

Solow, R. (1957): "Technical Change and the Aggregate Production Function", Review of Economics and Statistics, 39.

Siotis, G. (2000): "Market Power, Total Factor Productivity Growth and Structural Change. An Illustration for Spain, 1983-1996", Documento de Trabajo 2001, Servicio de Estudios, Banco de España.

Suarez, F. J. (1992):" Economías de Escala, Poder de Mercado y Externalidades. Medición de las Fuentes del crecimiento Español", Investigaciones Económicas, XVI, 3. 
Table 1.Basu-K imball Model

\begin{tabular}{cccccc}
\multicolumn{5}{c}{ Instrumental Variable Estimates (INST-1) } \\
\hline \hline \multicolumn{5}{c}{ Parameters } \\
& $\begin{array}{c}\text { Fixed } \\
\text { Effect }\end{array}$ & $\gamma^{F}$ & $a$ & $b$ & $c$ \\
\hline Sectors & & & & & \\
A & 2.7 & 1.24 & 1.08 & -1.76 & -0.31 \\
& $(1.0)$ & $(0.36)$ & $(1.37)$ & $(0.82)$ & $(0.54)$ \\
E & 1.2 & 0.21 & 5.22 & 1.05 & 0.09 \\
& $(0.5)$ & $(0.25)$ & $(6.17)$ & $(0.60)$ & $(0.04)$ \\
M1 & 0.4 & 1.10 & 0.60 & 1.04 & 0.36 \\
& $(0.6)$ & $(0.05)$ & $(2.00)$ & $(0.34)$ & $(0.23)$ \\
M2 & 0.9 & 1.08 & -0.41 & -1.09 & -0.00 \\
& $(0.2)$ & $(0.12)$ & $(2.40)$ & $(0.94)$ & $(0.12)$ \\
M3 & 1.1 & 0.96 & -1.00 & 1.21 & -0.22 \\
& $(0.8)$ & $(0.23)$ & $(3.94)$ & $(0.17)$ & $(0.55)$ \\
M4 & 1.2 & 0.93 & -0.81 & 1.91 & -0.35 \\
& $(0.3)$ & $(0.01)$ & $(1.55)$ & $(0.70)$ & $(0.14)$ \\
M5 & 0.9 & 0.99 & 1.49 & 0.91 & -0.17 \\
& $(0.3)$ & $(0.09)$ & $(0.97)$ & $(0.86)$ & $(0.32)$ \\
M6 & -0.3 & 1.0 & 1.72 & -4.25 & 0.15 \\
& $(0.2)$ & $(0.07)$ & $(3.41)$ & $(1.81)$ & $(0.29)$ \\
M7 & 1.4 & 0.52 & 1.95 & -3.44 & 0.37 \\
& $(0.6)$ & $(0.25)$ & $(3.33)$ & $(1.79)$ & $(0.45)$ \\
M8 & 0.6 & 0.74 & 2.13 & -2.59 & 0.59 \\
& $(0.4)$ & $(0.07)$ & $(0.93)$ & $(1.86)$ & $(0.15)$ \\
M9 & 0.5 & 0.73 & -4.08 & 0.61 & -0.03 \\
& $(0.2)$ & $(0.06)$ & $(1.25)$ & $(1.14)$ & $(0.34)$ \\
M10 & 1.0 & 0.85 & 0.47 & 0.41 & -0.04 \\
C & $(0.4)$ & $(0.10)$ & $(0.79)$ & $(0.19)$ & $(0.14)$ \\
S1 & 1.0 & 0.83 & -1.11 & -0.84 & 0.09 \\
S1 & $(0.3)$ & $(0.15)$ & $(3.60)$ & $(6.69)$ & $(0.34)$ \\
S2 & 1.8 & 0.61 & 1.34 & 1.51 & -0.17 \\
& $(0.6)$ & $(0.22)$ & $(1.24)$ & $(3.65)$ & $(0.31)$ \\
S3 & -0.5 & 1.42 & 0.11 & 0.69 & 0.10 \\
& $(0.8)$ & $(0.29)$ & $(1.29)$ & $(0.32)$ & $(0.20)$ \\
S4 & 3.8 & 0.92 & 8.97 & -0.61 & -0.18 \\
& $(0.8)$ & $(0.15)$ & $(3.01)$ & $(0.35)$ & $(0.06)$ \\
& 1.0 & 0.65 & 0.29 & 0.61 & -0.02 \\
& $(0.5)$ & $(0.18)$ & $(0.73)$ & $(0.44)$ & $(0.06)$ \\
& & & & & \\
& &
\end{tabular}

Note: INST-1 Instruments include: relative energy prices, world demand, fiscal impulse, and a monetary shock at time t and t- 1 ; and right hand side variables at $\mathrm{t}-1$. 
Table 1 (cont.). Basu-K imball M odel Aggregates

\begin{tabular}{cccccc}
\hline \hline & \multicolumn{6}{c}{ Parameters } \\
& $\begin{array}{c}\text { Fixed } \\
\text { Effect }\end{array}$ & $\gamma^{F}$ & $a$ & $b$ & $c$ \\
\hline Weighted Estimates & & & & & \\
Total Economy & 1.1 & 0.82 & 0.91 & 0.16 & 0.00 \\
Manufacturing & $(0.6)$ & $(0.19)$ & $(2.71)$ & $(2.89)$ & $(0.30)$ \\
Services & 0.6 & 0.92 & 0.53 & -0.23 & 0.08 \\
& $(0.4)$ & $(0.13)$ & $(2.59)$ & $(1.25)$ & $(0.32)$ \\
& 1.3 & 0.76 & 1.16 & 1.06 & -0.09 \\
& $(0.6)$ & $(0.22)$ & $(1.26)$ & $(2.68)$ & $(0.24)$
\end{tabular}

\section{Restricted Estimates}

Total Economy

Manufacturing

Services $\begin{array}{lllll}0.9 & 0.91 & -0.89 & 0.86 & 0.01\end{array}$

$\begin{array}{lllll}(0.7) & (0.05) & (2.29) & (0.42) & (0.10)\end{array}$

$\begin{array}{lllll}0.7 & 0.94 & -0.40 & 1.22 & 0.00\end{array}$

$\begin{array}{lllll}(0.3) & (0.04) & (1.30) & (0.40) & (0.13)\end{array}$

$\begin{array}{lllll}-2.7 & 2.03 & -0.55 & 2.55 & -0.15\end{array}$

$\begin{array}{lllll}(2.3) & (0.50) & (2.56) & (1.35) & (0.15)\end{array}$ 
Table 2. Restricted Basu-K imball M odel

Instrumental Variable Estimates (INST-1)

\begin{tabular}{|c|c|c|c|}
\hline & $\begin{array}{l}\text { Fixed } \\
\text { Effect }\end{array}$ & $\gamma^{F}$ & $a$ \\
\hline \multicolumn{4}{|l|}{ Sectors } \\
\hline $\mathrm{A}$ & $\begin{array}{l}3.0 \\
(0.3)\end{array}$ & $\begin{array}{l}1.37 \\
(0.09)\end{array}$ & $\begin{array}{l}1.88 \\
(0.59)\end{array}$ \\
\hline $\mathrm{E}$ & $\begin{array}{l}1.2 \\
(0.7)\end{array}$ & $\begin{array}{l}0.31 \\
(0.03)\end{array}$ & - \\
\hline M1 & $\begin{array}{l}0.5 \\
(0.1)\end{array}$ & $\begin{array}{l}1.22 \\
(0.01)\end{array}$ & $\begin{array}{l}5.65 \\
(0.30)\end{array}$ \\
\hline M2 & $\begin{array}{c}0.8 \\
(0.3)\end{array}$ & $\begin{array}{l}1.01 \\
(0.03)\end{array}$ & - \\
\hline M3 & $\begin{array}{l}1.5 \\
(0.1)\end{array}$ & $\begin{array}{c}0.89 \\
(0.03)\end{array}$ & - \\
\hline M4 & $\begin{array}{l}1.1 \\
(0.1)\end{array}$ & $\begin{array}{l}0.95 \\
(0.01)\end{array}$ & $\begin{array}{l}1.61 \\
(0.23)\end{array}$ \\
\hline M5 & $\begin{array}{c}0.9 \\
(0.2)\end{array}$ & $\begin{array}{l}1.07 \\
(0.03)\end{array}$ & $\begin{array}{l}1.50 \\
(0.54)\end{array}$ \\
\hline M6 & $\begin{array}{c}0.1 \\
(0.1)\end{array}$ & $\begin{array}{l}0.98 \\
(0.07)\end{array}$ & - \\
\hline M7 & $\begin{array}{c}0.4 \\
(0.1)\end{array}$ & $\begin{array}{l}0.84 \\
(0.06)\end{array}$ & - \\
\hline M8 & $\begin{array}{c}0.8 \\
(0.2)\end{array}$ & $\begin{array}{l}0.87 \\
(0.05)\end{array}$ & $\begin{array}{l}2.72 \\
(0.64)\end{array}$ \\
\hline M9 & $\begin{array}{c}0.7 \\
(0.2)\end{array}$ & $\begin{array}{l}0.71 \\
(0.06)\end{array}$ & - \\
\hline M10 & $\begin{array}{c}0.9 \\
(0.1)\end{array}$ & $\begin{array}{l}0.92 \\
(0.03)\end{array}$ & - \\
\hline $\mathrm{C}$ & $\begin{array}{l}1.0 \\
(0.1)\end{array}$ & $\begin{array}{l}0.85 \\
(0.03)\end{array}$ & - \\
\hline $\mathrm{S} 1$ & $\begin{array}{l}1.2 \\
(0.4)\end{array}$ & $\begin{array}{l}0.69 \\
(0.10)\end{array}$ & - \\
\hline $\mathrm{S} 2$ & $\begin{array}{l}1.0 \\
(0.3)\end{array}$ & $\begin{array}{l}1.33 \\
(0.12)\end{array}$ & $\begin{array}{l}1.37 \\
(0.78)\end{array}$ \\
\hline $\mathrm{S} 3$ & $\begin{array}{l}3.2 \\
(0.8)\end{array}$ & $\begin{array}{l}1.01 \\
(0.11)\end{array}$ & $\begin{array}{l}4.47 \\
(1.00)\end{array}$ \\
\hline $\mathrm{S} 4$ & $\begin{array}{c}0.5 \\
(0.4)\end{array}$ & $\begin{array}{l}0.96 \\
(0.11)\end{array}$ & - \\
\hline
\end{tabular}

Note: INST-1 Instruments include: relative energy prices, world demand, fiscal impulse, and a monetary shock at time $\mathrm{t}$ and $\mathrm{t}-1$; and right hand side variables at $\mathrm{t}-1$. 
Table 2 (cont.) Restricted Basu-K imball M odel Instrumental Variable Estimates (INST-1)

\begin{tabular}{cccc}
\hline \hline & & & \\
& $\begin{array}{c}\text { Fixed } \\
\text { Effect }\end{array}$ & $\gamma^{F}$ & $a$ \\
\hline Weighted Estimates & & & \\
Total Economy & 1.0 & 0.90 & 0.79 \\
Manufacturing & $(0.3)$ & $(0.08)$ & $(0.32)$ \\
Services & 0.7 & 0.98 & 1.34 \\
& $(0.1)$ & $(0.05)$ & $(0.27)$ \\
& 1.1 & 0.87 & 0.39 \\
& $(0.4)$ & $(0.11)$ & $(0.36)$ \\
Restricted Estimates & & & \\
Total Economy & & & \\
Manufacturing & 1.0 & 0.96 & 5.07 \\
Services & 0.6 & 0.95 & $(2.57)$ \\
& $(0.4)$ & $(0.03)$ & $(1.42)$ \\
& 0.8 & 0.99 & 4.00 \\
& $(0.7)$ & $(0.16)$ & $(2.27)$
\end{tabular}


Table 3. R eturns to Scale and Technology Growth Gross Production vs. Value Added

\begin{tabular}{ccccc}
\hline \hline & \multicolumn{2}{c}{ Technology Growth } & \multicolumn{2}{c}{ Returns to Scale $(\gamma)$} \\
& & & & \\
Production & Value Added & Production & Value Added \\
\hline A & 3.0 & 8.2 & 1.37 & 2.08 \\
E & 1.2 & 1.4 & 0.31 & 0.14 \\
M1 & 0.5 & 7.8 & 1.22 & 3.07 \\
M2 & 0.8 & 1.9 & 1.01 & 1.03 \\
M3 & 1.5 & 4.4 & 0.89 & 0.68 \\
M4 & 1.1 & 3.2 & 0.95 & 0.86 \\
M5 & 0.9 & 3.0 & 1.07 & 1.29 \\
M6 & 0.1 & 1.0 & 0.98 & 0.91 \\
M7 & 0.4 & 1.3 & 0.84 & 0.60 \\
M8 & 0.8 & 1.9 & 0.87 & 0.70 \\
M9 & 0.7 & 1.5 & 0.71 & 0.44 \\
M10 & 0.9 & 2.3 & 0.92 & 0.79 \\
C & 1.0 & 2.4 & 0.85 & 0.63 \\
S1 & 1.2 & 2.0 & 0.69 & 0.56 \\
S2 & 1.0 & 1.3 & 1.33 & 1.61 \\
S3 & 3.2 & 3.1 & 1.01 & 1.02 \\
S4 & 0.5 & 0.7 & 0.96 & 0.95 \\
& & & & \\
Total Economy & 1.0 & 2.6 & 0.90 & 0.98 \\
Manufacturing & 0.7 & 3.2 & 0.98 & 1.19 \\
Services & 1.1 & 1.5 & 0.87 & 0.84 \\
& & & &
\end{tabular}


Table 4. From Productivity (Solow) to Technology Growth 1980-1995 estimates (value added based)

\begin{tabular}{lccc|ccc} 
& \multicolumn{5}{c}{ Averages } & \multicolumn{5}{c}{ Correlation with Output } \\
\hline & Aggte. & Manuf. & Serv. & Aggte. & Manuf. & Serv. \\
Productivity (Solow) & 2.39 & 2.45 & 1.12 & -0.06 & 0.09 & 0.21 \\
Departure from CR S & -0.13 & -0.58 & -0.27 & & & \\
Variable Utilization & -0.01 & 0.05 & 0.00 & & & \\
R eallocation Factors & & & & & & \\
Total & -0.06 & -0.25 & -0.09 & -0.35 & -0.24 & -0.16 \\
Intermediate Inputs & 0.02 & -0.50 & 0.02 & & & \\
Markups & -0.53 & -0.50 & -0.20 & & & \\
Technology Other & 0.44 & 0.76 & -0.09 & & & \\
& 2.60 & 3.23 & 1.55 & 0.15 & -0.05 & 0.44
\end{tabular}

Table 5. From Productivity (Solow) to Technology Growth 1980-1999 estimates (value added based)

\begin{tabular}{lccc|ccc} 
& \multicolumn{5}{c}{ Averages } & \multicolumn{3}{c}{ Correlation with Output } \\
\hline & Aggte. & Manuf. & Serv. & Aggte. & Manuf. & Serv. \\
Productivity (Solow) & 1.98 & 1.97 & 0.90 & -0.20 & -0.02 & 0.18 \\
Departure from CR S & -0.16 & -0.44 & -0.31 & & & \\
Variable Utilization & -0.02 & 0.03 & -0.07 & & & \\
Reallocation Factors & & & & & & \\
Total & -0.09 & -0.23 & -0.06 & -0.22 & -0.14 & -0.17 \\
$\quad$ Intermediate Inputs & -0.02 & -0.47 & 0.02 & & & \\
Markups & -0.45 & -0.37 & -0.21 & & & \\
Other & 0.38 & 0.60 & 0.14 & & & \\
Technology & 2.23 & 2.62 & 1.34 & -0.05 & -0.20 & 0.41
\end{tabular}


FIGURE 1. SOLOW RESIDUAL AND TECHNOLOGY GROWTH

(Value Added based)

(a) NON-FINANCIAL MARKET ECONOMY

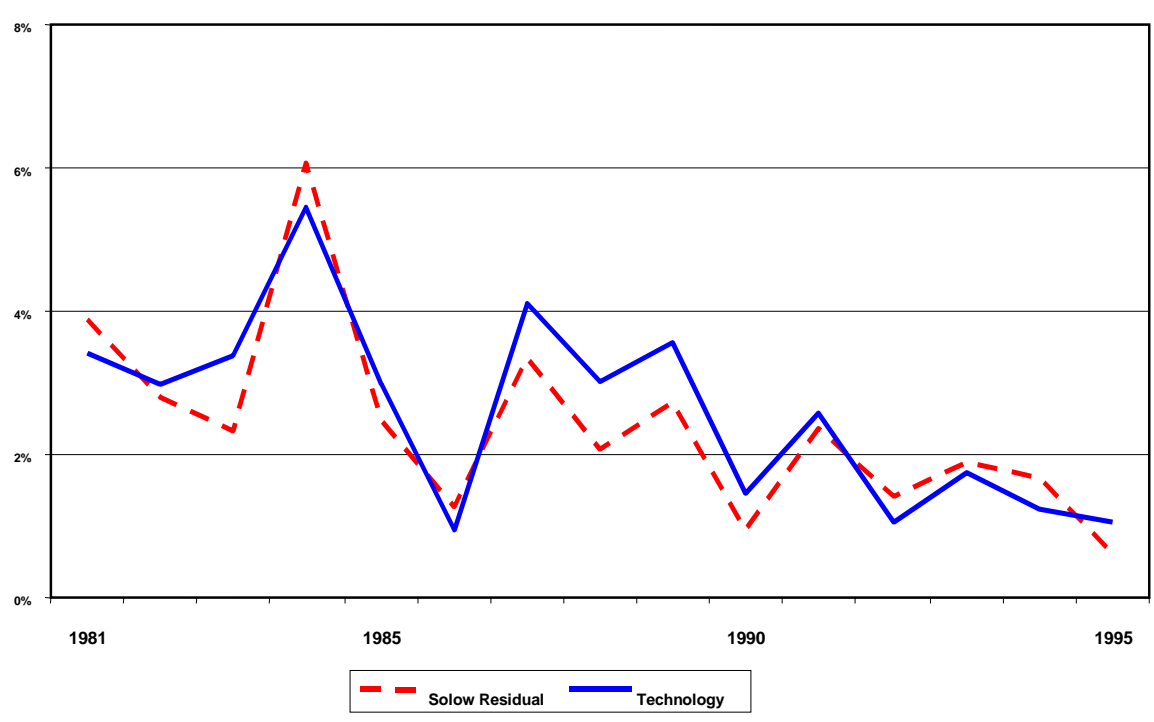

(b) MANUFACTURING SECTOR

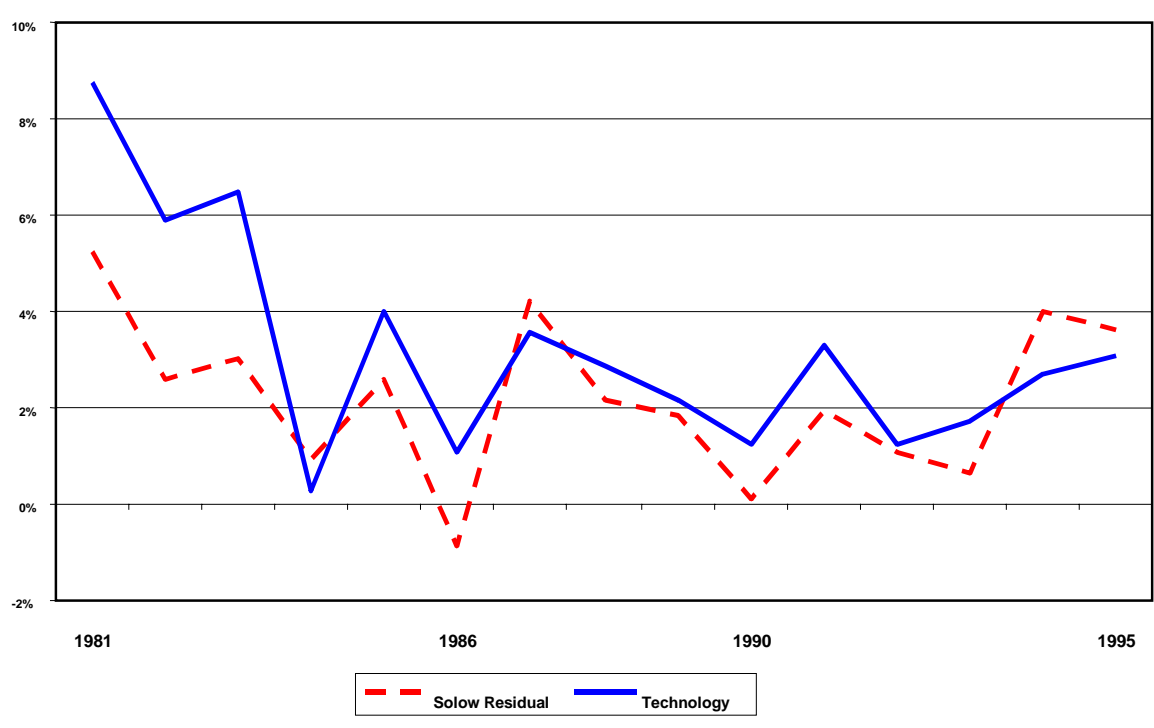

(c) SERVICES SECTOR

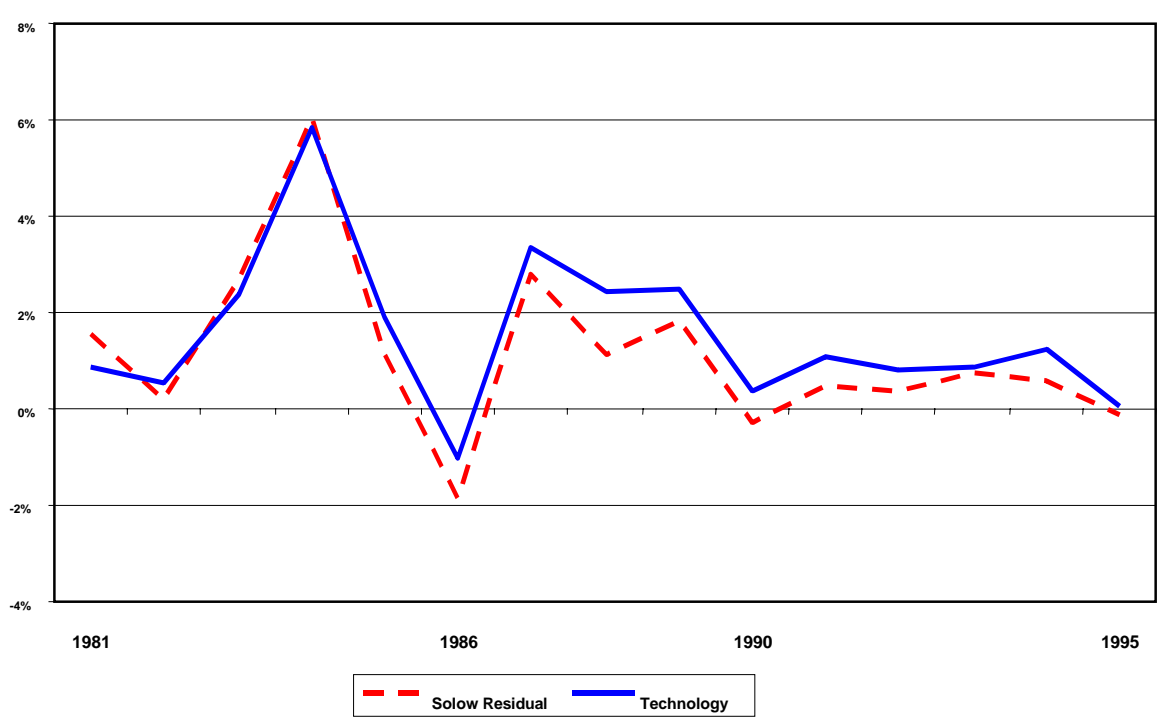


FIGURE 2. THE DIFFERENCE BETWEEN SOLOW AND TECHNOLOGY The role of Reallocation Factors. (Value Added based)

(a) NON-FINANCIAL MARKET ECONOMY

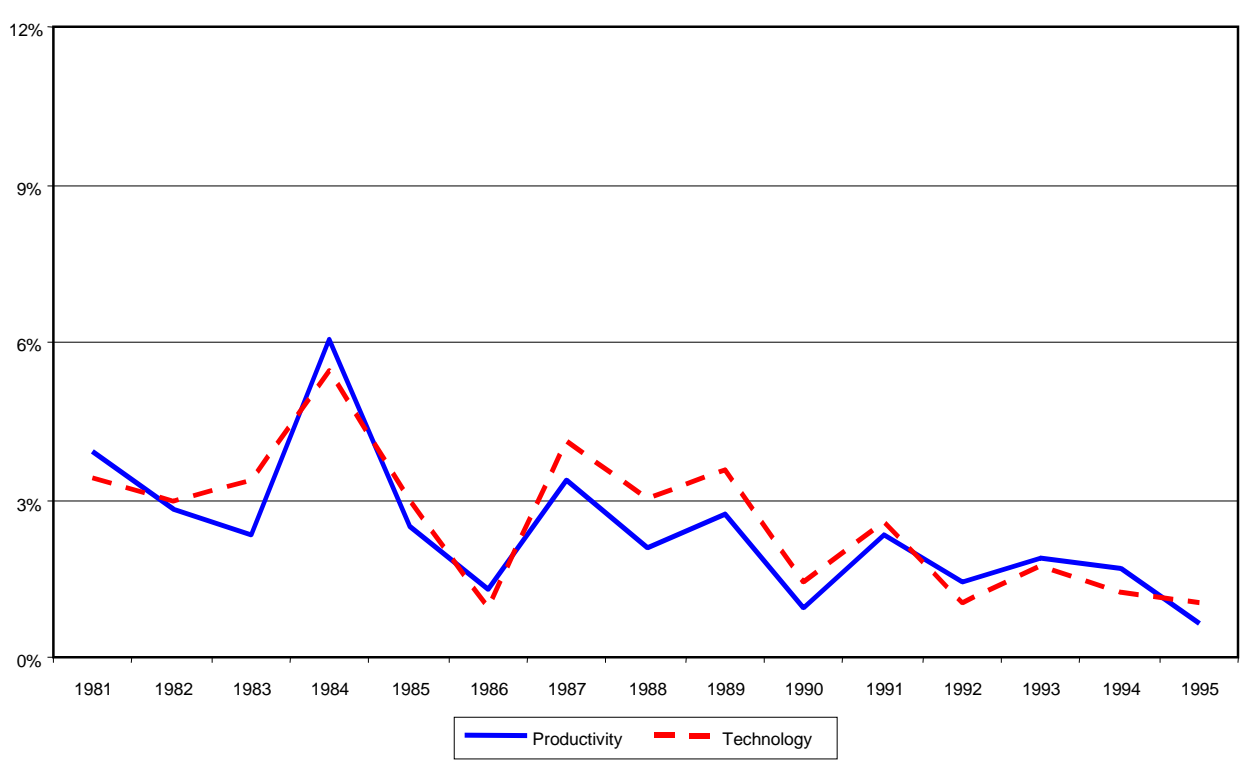

(b) REALLOCATION COMPONENTS

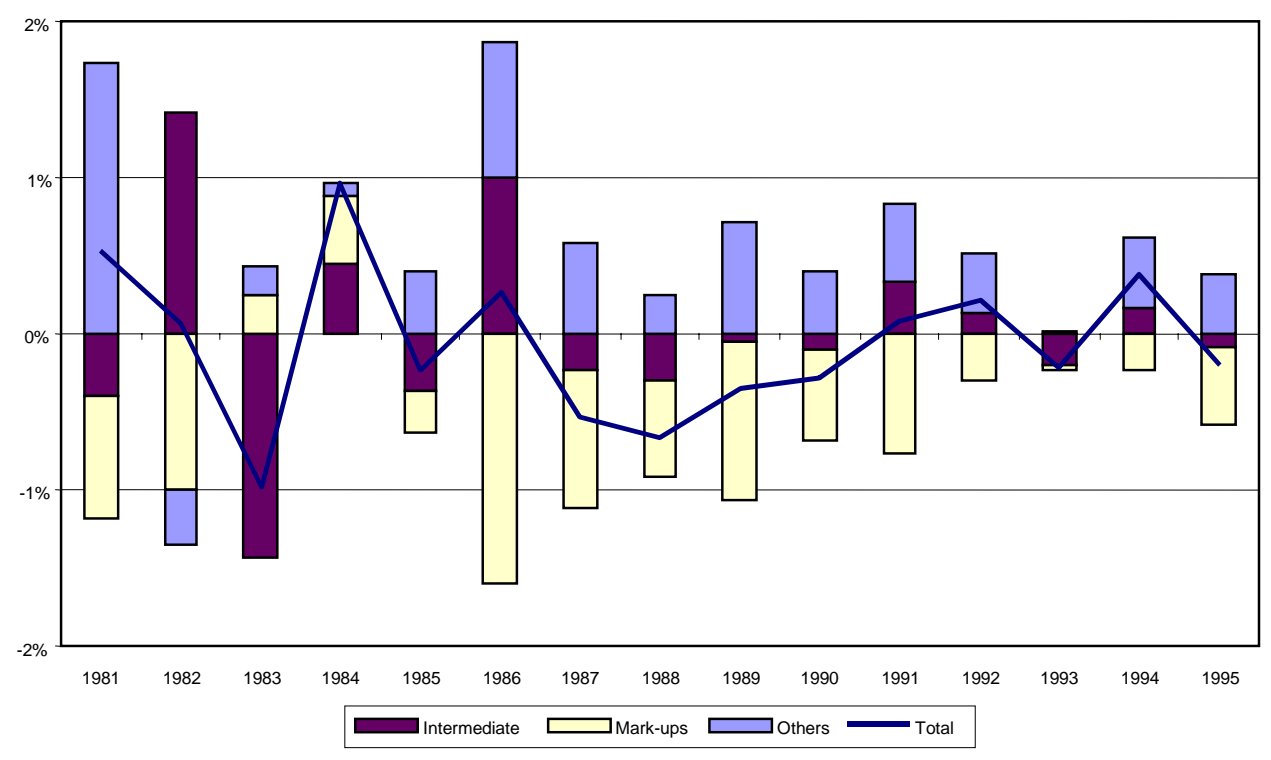


FIGURE 3. THE DIFFERENCE BETWEEN SOLOW AND TECHNOLOGY The role of Reallocation Factors. (Value Added based)

(a) MANUFACTURING SECTOR

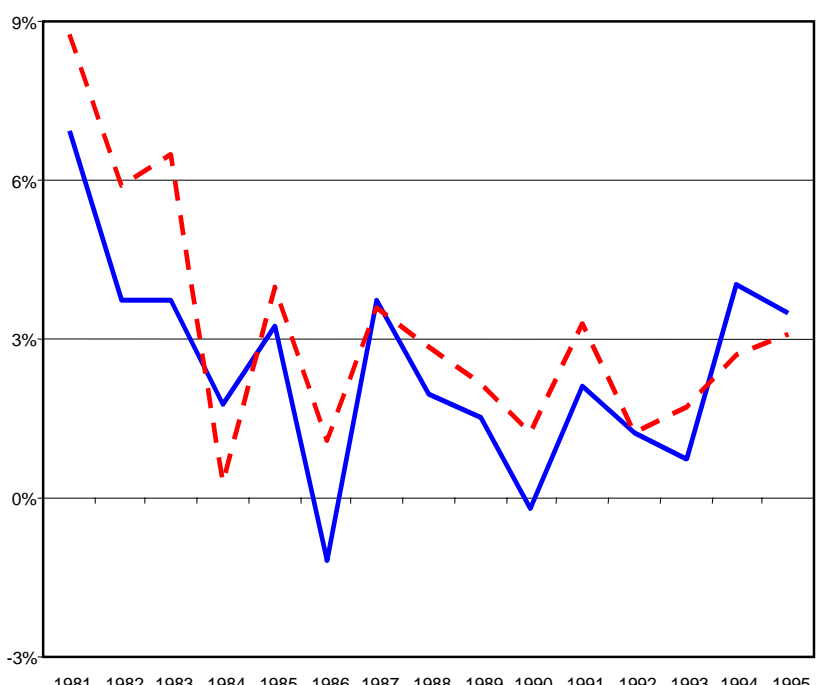

Productivity $-\quad-$ Technology

(b) REALLOCATION COMPONENTS

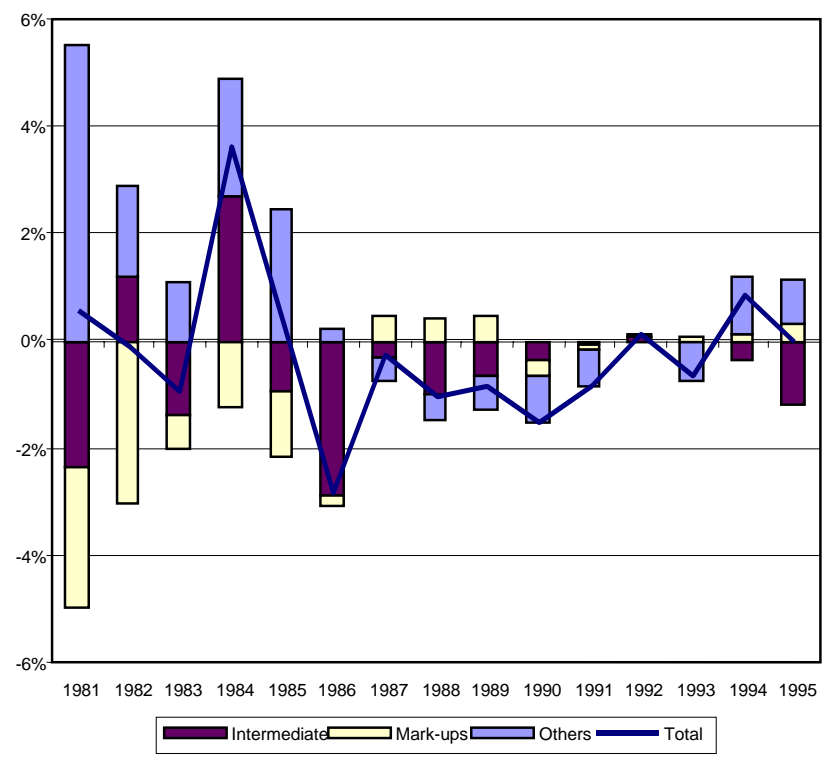

(c) SERVICES SECTOR

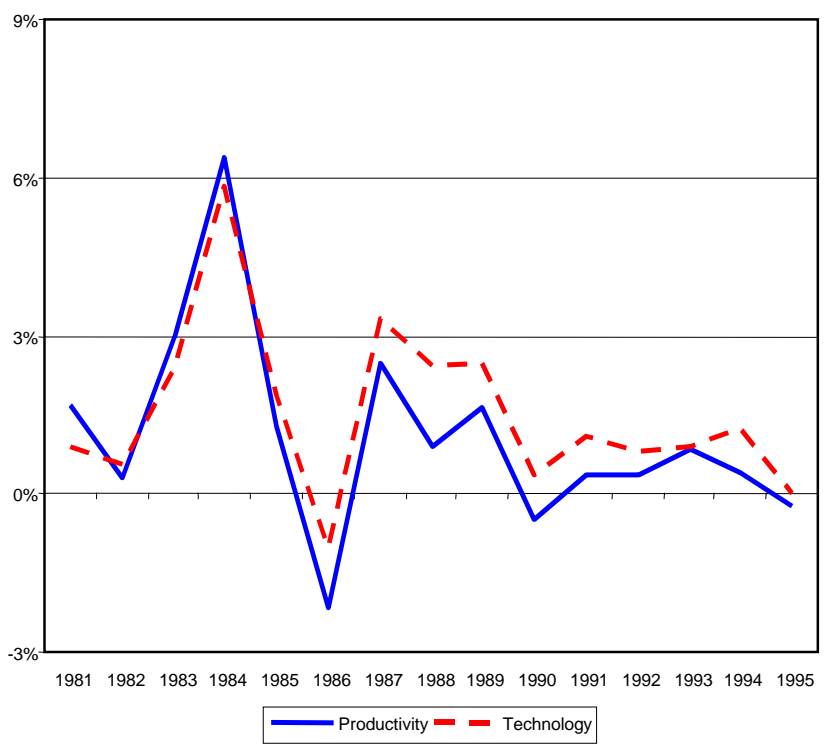

(d) REALLOCATION COMPONENTS

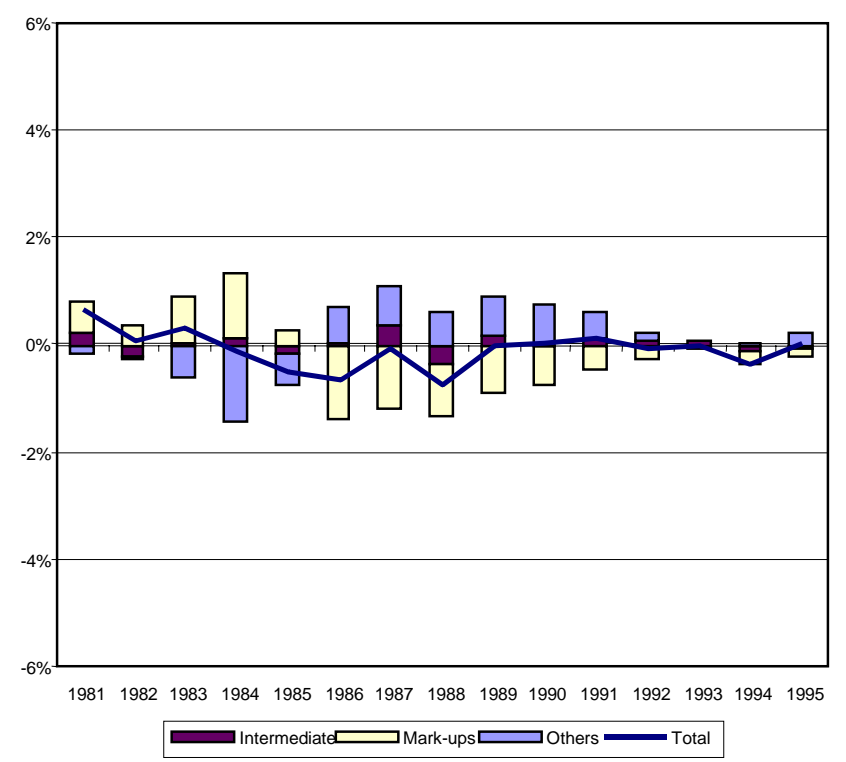


FIGURE 4. PRODUCTIVITY VS. TECHNOLOGY LEVELS

(Value Added based)

(a) NON-FINANCIAL MARKET ECONOMY. 1980=100

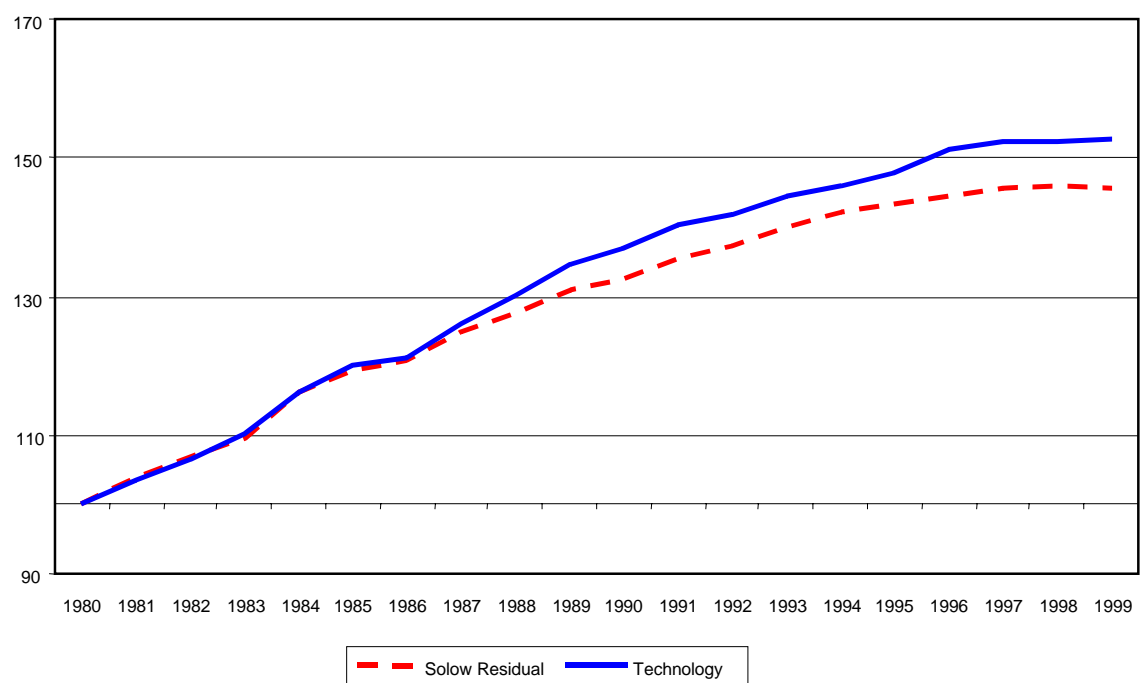

(b) MANUFACTURING SECTOR. $1980=100$

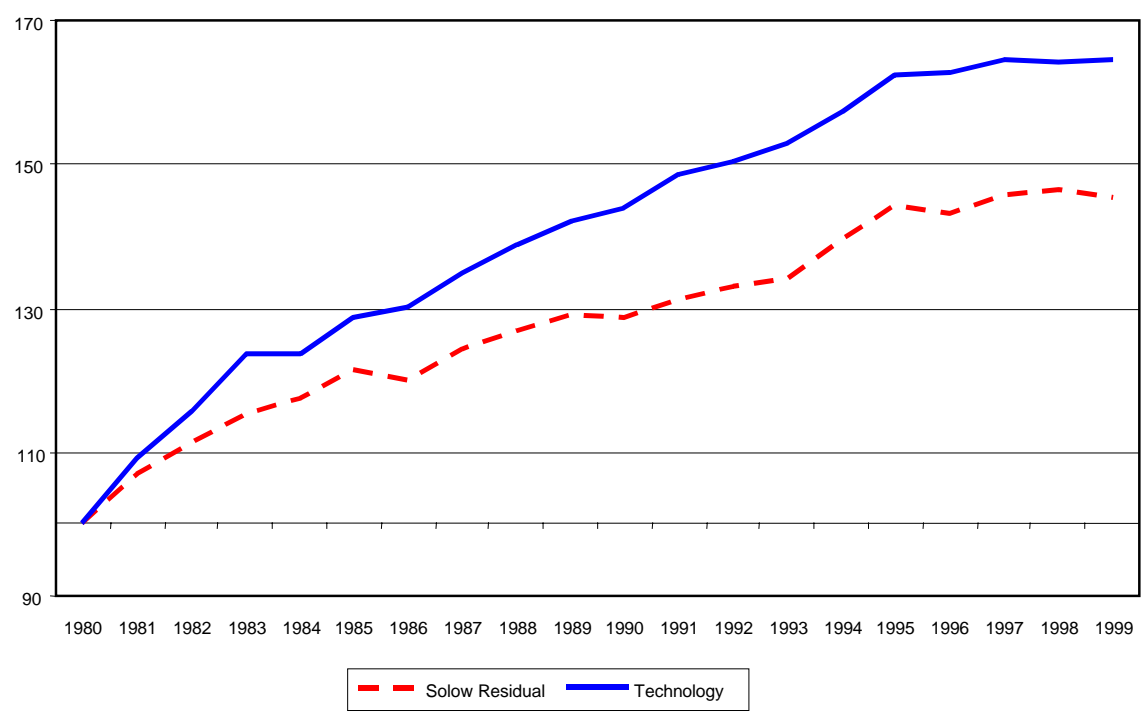

(c) MARKET SERVICES SECTOR. 1980=100

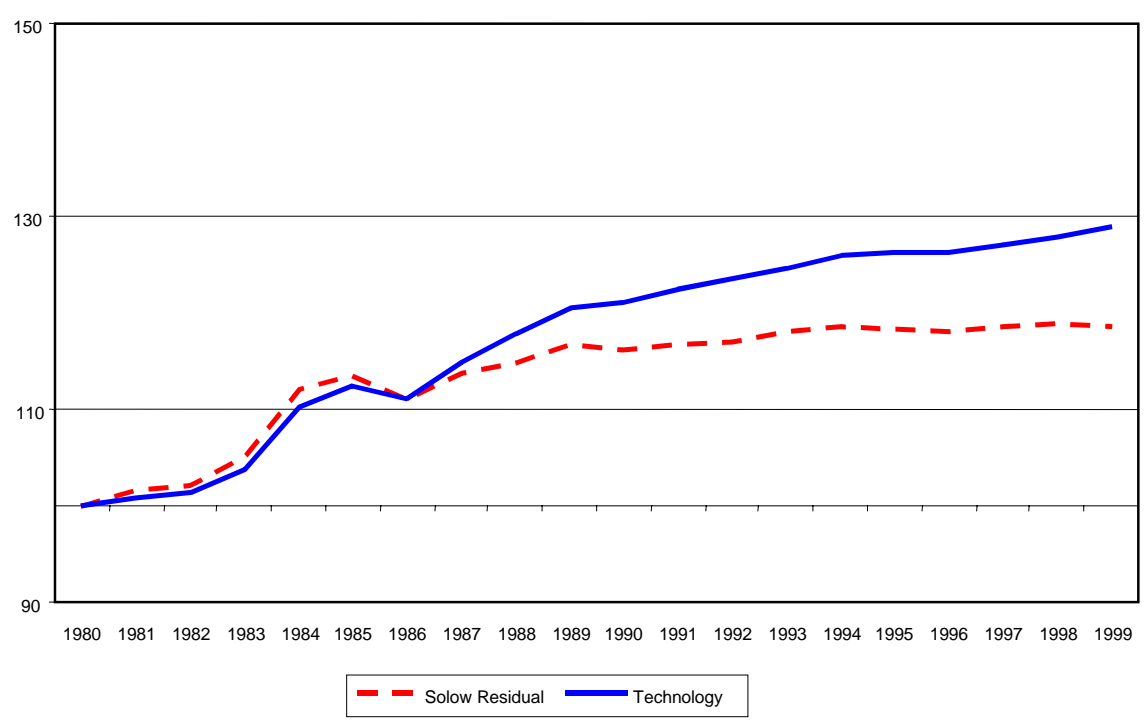

